UNITED STATES

DEPARTMENT OF THE INTERIOR

GEOLOGICAL SUAVEY

SUMMARY OF REFERENCES TO MINERAL OCCURRENCES

(OTHER THAN MINERAL FUELS AND CONSTRUCTION MATERIALS)

IN THE DILLINGHAM, SLEETMUTE, AND TAYLOR MOUNT ADNS QUADRANGLES,

ALASKA

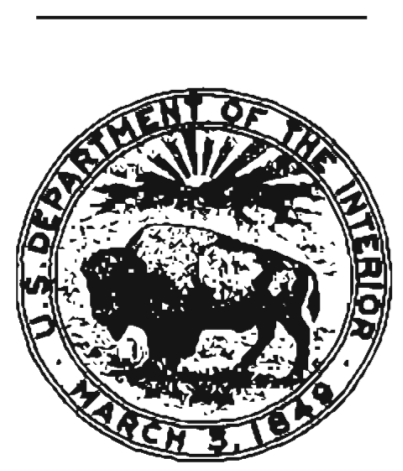

FIOPERTY $C$ E

Ligt:

tate ar Risata

Deflaidit 28

GEOLOGILAL EURVY

OPEN-FILE REPORT 76-606

This roport is preliminary and hes not

beon edited or reviewed for conformity

with Geolosical Survey standards and

nomonctature

Menlo Pork, Callfomla

1976 
UNITED STATES DEPARTMRNT OF THE INTERIOR

GEOLOGICAL SURVEY

\section{SOMMARY OF REFERENCES TO MINERAL OCCURRENCES \\ (OTHER THAN MINERAL FUELS AND CONSTRUCTION MATERIALS) \\ IN THE DILLINGEAM, SLBETMUTE, AND TAYLOR MOUNTAINS QUADRANGLES, ALASKA}

By

Edward R. Cobb

Open-f1le Report 76-606

Th1s report 1s prelimlary and has not been edited or reviewed for conformsty with Geologlcal Survey atandards and nomenclature. 


\section{Introduction}

These sumaries of references are designed to ald in library research on metalle and nonmetallic (other than mineral fuels and construction materlals) mineral occurrences in the Dillingham, Sleetmute, and Taylor Mountafne quadrangles in southwestern Alaska. All references to reports of the Geological Survey, to most reports of the U.S. Bureau of Maes, and to most reports of the State of Alaska Division of Geological and Geophysical Surveyg and 1ta predecessor State and Territorlal agencles released before January 1, 1976, are summarized. Certaln, ma1nly statistical, reports such as the annual Minerals Yearbook of the U.S. Bureau of Mines and the biennial and annual reports of the State of Alaska Division of Geologlcal and Geophysical Surveys and Its predecessor State and Territorlal agencles are not 1ncluded.

Thls report 18 divided into three parts: a section made up of summarles of references arranged alphabetically firat by quadrangle and second by occurrence name; a sectlon that 11 sts byononms for names in the f1rst section, clatm names, and the nomes of operators and owners of mines and prospects; and a section that 118ts, by author, all references oummarlzed In the first section. 


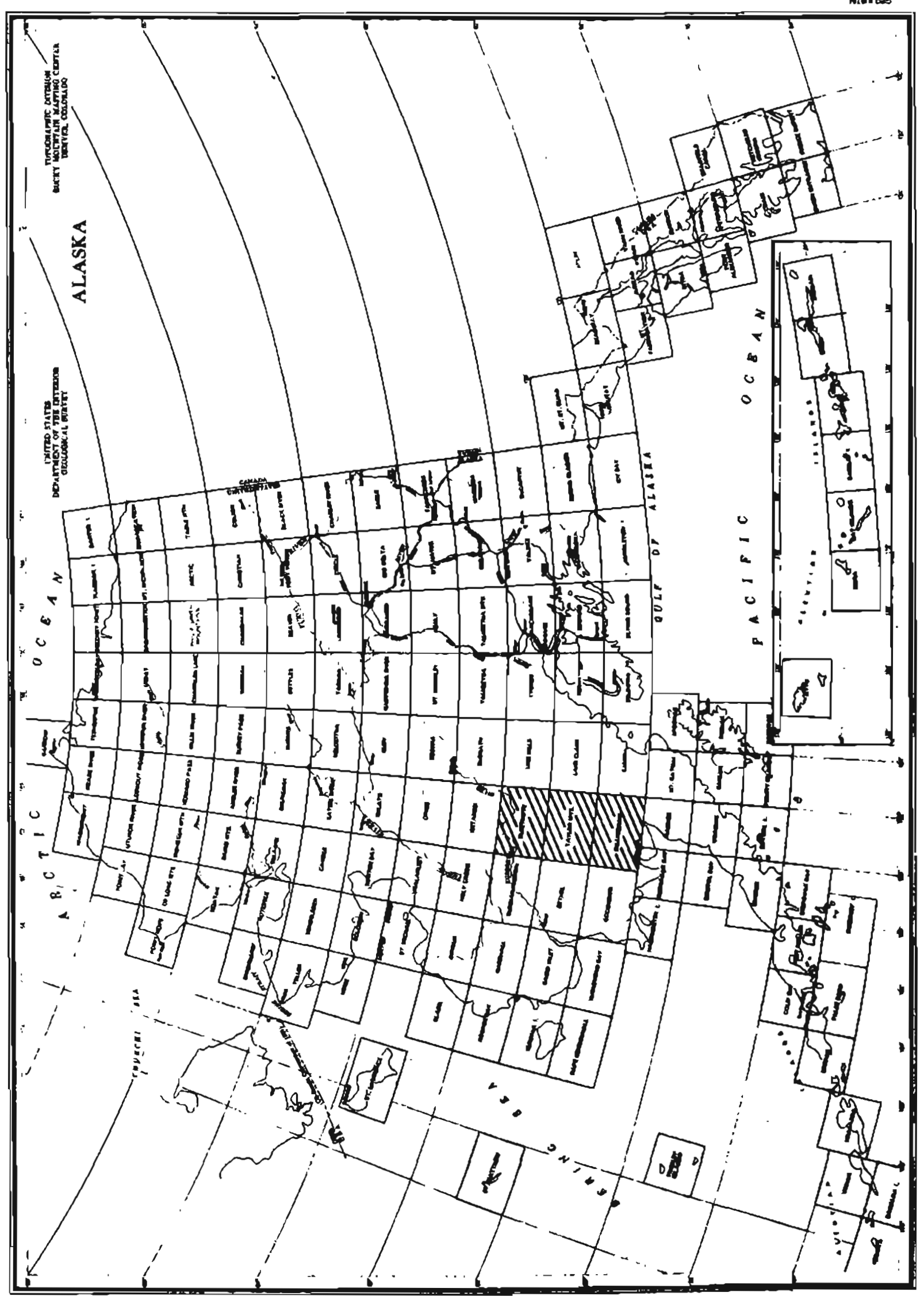




\section{Summarles of References}

For each mineral occurrence there is a page that gives the name of the occurrence; the mineral comodities present (11sted alphabetically for metallic comodities and then for nonmetalif commodities); the minlng distrlct (Ransome and Kerns, 1954) in which the occurrence 1s located; the name of the 1:250,000-8cale topograph1c quadrangle; coordinates (as described by Cobb and Kachadoor1an, 1961, p. 3-4); the metal11c mineral resources map number (Cobb, 1972, In the reference 118t for each quadrangle) and the occurrence number on that map if the occurrence is shown; and the latitude and longitude of the occurreace. These data, pregented at the top of the page, are followed by a short, general sumary of the published 1nformation on the occurrence. Th1s 18 followed (continued on additlonal pages, if necersary) by more detalled summarles, arranged chronologlcally, of all references to the occurrence. Material in brackets 1s interpretive or explanatory and is not in the summarized reference.

Proper names of mlnes, prospects, and other m1neral occurrences are given If such names appear in the reports sumarlzed. If a deposit does not have such a name, but 18 near a named geographic festure, the name of that feature 18 shown in parentheses in lieu of a proper name. If a deposit has no proper name and is not near a named geographle feature, 1 is titled "Unnamed occurrence" and appears at the end of the 11st. If a part of a. proper name 18 not always used in a reference, that part of the name 18 shown In parentheses. This is most comon in company names and in place names wth minor varlations in spelling.

Cltations are given in gtandard bibllographic format with the exception that references to reports and maps in aumbered publication ser1es also show, 
In pareatheses, an abbreviation for the report or map series and the report or nap nuber. Abbrevlations used are:

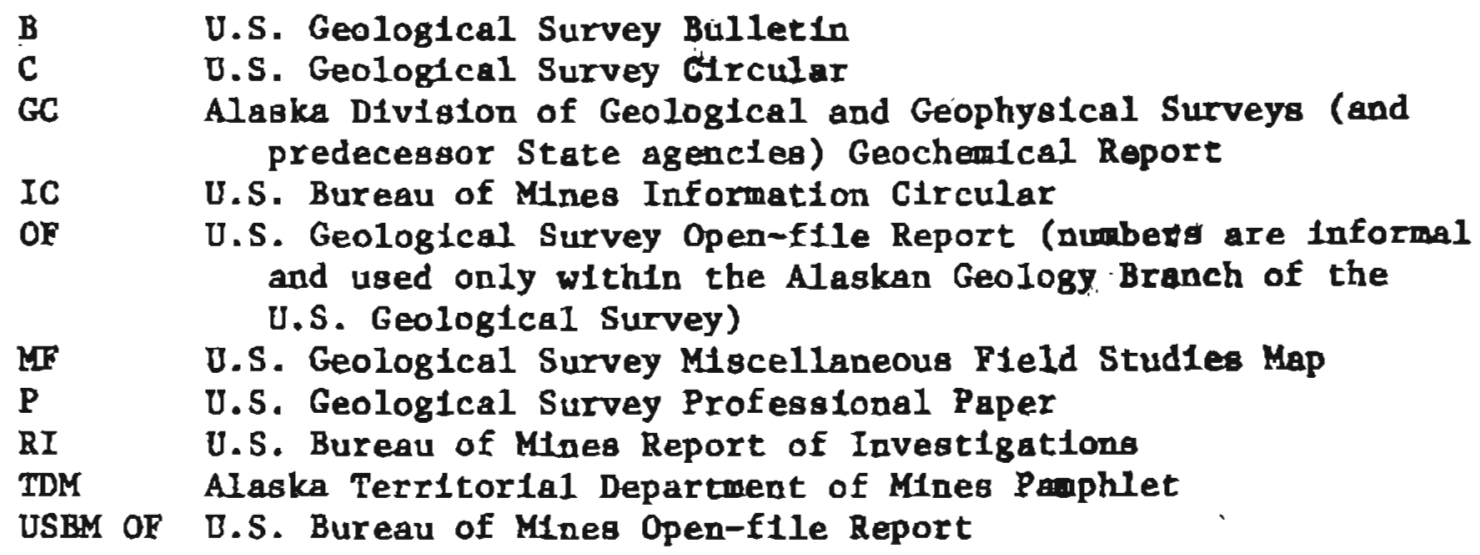

Sumarles are as I made them whle reading the clted reports. I made no attempt to use couplete sentences and did not edit for gramatical consiatency, although I have trled to edt out ambigulties.

References cited only in these introductory paragraphs are:

Cobb, E. H., and Kachadoor1an, Reuben, 1961, Index of metallic and nometallic mineral depostta of Alaska complled from published reporta of Federal and State agencles through 1959: U.S. Geol. Survey Bull. 1139, 363 p. Rangome, A. L., and Kerns, W. H., 1954, Names and definitiong of reg1ons, districts, and subdistricts In Alaska (used by the Bureau of Mines in statistical and economlc studies covering the mineral industry of the Territory): U.S. Bur. Mines Inf, C1rc. 7679, 91 p. 
Bristol Bay region

D1111ngham (11.25-12.3, 11.7-12.7)

MF-375, 10C. 2

$$
59^{\circ} 40^{\circ}-59^{\circ} 47^{\prime} \mathrm{N}, 157^{\circ} 36^{\prime}-157^{\circ} 43^{\prime} \mathrm{W}
$$

Summary: A burled deposit of t1taniferous magnetite disseminated In pyroxenite containg several billion tons of material containing 15-17 percent total 1ron. No ore has been produced.

Berg and Cobb, 1967 (B 1246), p. 11 -- Large burled Iron depostt discovered by atrborne geophysical exploration in 1959. Exploratory diamond dr1111ng dieclosed several billion tons of material contalning 10.5-12 percent magnetite 1ron and 15-17 percent total 1ron. Deposit is titaniferous magnetite disseminated in pyroxenite.

Eakins, 1968 (GC 17), p. B -- Large low-grade magnet1te deposit; several b1111on tons of material contalning 15-17 percent total 1ron. 
(Koktalee R.)

Br1stol Bay region
Go1d

D11lingham

NE $1 / 4$ NE $1 / 4$ quad. (?)

Sumbary: Fine flour gold on river bars.

Katz, 1910 (B 442), p. 202 -- Preliminary to 8485.

Martin and Katz, 1912 (B 485), p. 133 -- Fine flour gold found on all river bars. Sm1th, 1915 (B 622), p. 263 ... Quotation from B 485.

Smith, 1917 (B 655), p. 136 - Quotation from B 485. 
(Lake Nerka)

Bristol Bay region
Gold

D1llingham $(1.75,9.0)$ approx. $59^{\circ} 30^{\circ} \mathrm{N}, 158^{\circ} 45^{\prime} \mathrm{W}$ approx.

Summary: A Ilttle placer gold reported.

Bak1ns, 1968 (GC 17), p. 8 - A 11ttle placer gold reportedly was found at a sma11 lake between the two arms of Lake Nerka. 
(Marsh Men.)

Bristol Bay region

MF-375, 10c. 3
Mercury

D1llingham $(4.15-4.25,1.6-2.1)$ $59^{\circ} 02^{\prime} \mathrm{N}, 158^{\circ} 32^{\prime} \mathrm{W}$

Summary: Graywacke and shale of Gemuk Gp. (Carboniferous (?) to Cretaceous) In open fold cut by major fault zone with undetermined amount of right-lateral diaplacement. Fault zone is complex1y sheared and brecclated through width of more than $100 \mathrm{ft}$. Cinnabar 18 the only ore atneral and occura disseminated and as pods and velnlets up. to $4 \mathrm{fn}$. wide and $30 \mathrm{ft}$. long. Gangue 18 dolomite or ankeritic dolomite, calctte, and locally dicktte. Ore locallzed along open channels; some depostted in open spaces; some replaced breccla fragments and dolomite. Ore only where wall rock 18 graywacke. Placer dinnabar discovered in Arcana $\mathrm{Cr}$. In 1941 and traced to lode source in 1942. Lode explored by $10,000 \mathrm{ft}$. of trenches and $560 \mathrm{ft}$. of underground workings. Production (all from lode) was 60 flasks of mercury; more ore stockpiled. Placer deposit thin and lean. Includes references to: (Arcana Cr.), Feeder, Red Top, 3 " $W$ ".

Joesting, 1943 (TDM 2), p. 18 -- A cinnabar lode and assoclated placers reported by Frank Waskey, 1942 or early 1943.

Webber and others, 1947 (RI 4065), p. 54-57 - Placer clnnabar found In Arcana Cr., 1941; 4 placer clalms staked. Float traced to lode, 1942. Test shipment of 470 lbs. h1gh-grade hand-plcked ore from prospect p1to, 1942; analyzed 1,287 1bs. mercury per ton. Placers are shallow, poorly sorted, and contain only a little cinnabar in pleces up to half an ounce; richest In fan at mouth of a tributary that drains area of lode. Sampling and slutclag from a small cut showed no more than $1.66 \mathrm{lbo.} \mathrm{mercury} \mathrm{per} \mathrm{cu.} \mathrm{yd.;}$ some of cinnabar on clay false bedrock. Lode appears to be along bedding planes in graywacke. A few trenches and p1ts exposed erratic ore zones of cinnabar and calcite.

Pennington, 1959 (IC 7941), P. 12 -- Recent explorat1on; ore estimated to contaln 1,400 flasks of mercury was discovered.

P. 85 -- DMEA contract.

Salnsbury and Mackevett, 1960 (P 400-B), p. B36-B38 - Mine has had amal1 production. Ore along a steep fault zone where 1 t intersects minor foldg that plunge southward. Fault zone 1a parallel to reglonal att1tude of graywackes and alltatones of Gemuk GP. (Carbon1ferous to Cretaceous). Ore 1a clnnabar In dolomte gangue; locallzed in breccla zones and velnlets along fractuxes in graywacke; no cinnabar in siltstone. Two ad1ta; some material on a dump runs $1.1 \% \mathrm{HB}$.

Malone, 1962 (IC 8131), p. 8 -- Had been found before World War II; reference to RI 4065 .

p. 51-54 - Ore in brecclated zone (100 or more feet wide) in graywacke; ore in 2 parallel serles of stringers about $50 \mathrm{ft}$. apart. $550 \mathrm{ft}$. of drifts and crosscuts (DMEA contract). Mineralization extends downward wthout improvement In grade. A few flasks of mercury has been produced. Malone, 1965 (IC 8252), p. 32-33, 51, 56 -- Same as IC 8131.

Salnsbury and Mackevet, 1965 (B 1187), p. 3 -- Ore (not yet fully explored) was discovered with DMEA loan.

p. 57-66 - Placer cinnabar discovered 1n Arcana Cr. In 1941 and traced to lodes. Under DMRA contracts $10,000 \mathrm{ft}$. of bulldozer trenches were 
(Marsh Mtn.) - Contlaued

excavated and $560 \mathrm{ft}$. of underground workings dr1ven; another ad1t drivea by mining companies (1952-58); total production was 60 flasks of mercury; ore that would $y$ teld at least as much was stockp1led In 1959. Area 1s underlain by graywacke and ofltotone of the Gemak Gp. (Carbontferous (?) to Cretaceous); falrly open folde. Fault zone with an undetermined amount of rlght-lateral displacement is complexly sheared and brecclated (particularly noticeable in underground workings); more than $100 \mathrm{ft}$. wlde. Cinnabar 1s only ore mineral (no stibntte); gengue $1 \mathrm{~s}$ dolomite or ankeritic dolomite and calclte; locally some dicktte; quartz scarce. Some arglilized rock contains specks of pyrite. Mineralizing solutions Introduced along fault zone; ore deposiced along open channela. Some ore replaced breccla fragments and dolomlte. Some movement along faults was post-ore. All clnnabar where wall rock 1s graywacke; none In siltstone.

Berg and Cobb, 1967 (B 1246), p. 11 -- Cinnabar localized along a 100-foot-w1de steeply dipping lault zone cutting folded graywacke and alltstone. Gangue is secondary 1ron minerals, dolomte, and mfnor amounta of clay. About 60 flasks of mercury recovered, 1952-55.

Bakins, 1968 (GC 17), p. 4 - Reference to B 1187 and statement that in 1967 stockplled ore was belng hand sorted.

p. 7-8 -- Dlscovered, 1941. Ore locallzed along open channels in zone where a mafor fault zone cuts a large fold. $10,000 \mathrm{ft}$. of trenching and $560 \mathrm{ft}$. of ad1ts and drifts exposed a 100-foot-wlde shear zone that can be traced on surface for 2,000 ft. Clnnabar occurs as fine diseeminations and as pods and velnlets up to $4 \mathrm{ln}$. wide and $30 \mathrm{ft}$. long. Limonite assoclated wth depostt; no stibnite.

Hawley and others, 1969 (C 615), p. 18-20 - Reference to B 1187. Analyses of 2 ore samples; gold less abundant than in several common rock types. 
(Muklung H1118)

Bristol Bay region
Gold

D1111ngham $(7.0,7.0)$ approx. $59^{\circ} 25^{\circ} \mathrm{N}, 158^{\circ} 15^{\prime}$ ' approx.

Sumary: Coarse gold on tributary of Kokwok R. On NE slopes of Muklung R111s.

Mertie, 1938 (B 903), p. 91 -- Some coarse gold has been found In a tributary of the Kokwok R. along the NE slopes of the Muklung Bills.

Eak1n, 1938 (GC 17), P. 8 - Placer gold has been found on NE s1de of Muklung H1118. 
(Mulchatna R.)

Brfstol Bay region
Gold

Delingham

NE $1 / 4$ quad.

Summary: Fine flour gold on rlver bars above mouth of Roktalee (Roktuli) R. Some of very small amount of gold from Mulchata R. probably comes from part of stream in Dillingham quadrangle.

Katz, 1910 (B 442), p. 202 -- Preliminary to B 485.

Martin and Katz, 1912 (B 485), P. 133 - Flne flour gold on all river bars above Roktalee $\mathbf{R}$.

Sm1th, 1915 (B 622), P. 263 -- Quotation from B 485.

Sm1th, 1917 (B 655), p. 136 -- Quotation from B 485.

Cobb, 1973 (B 1374), p. 12 -- Mulchatna R. known to be auriferous and the source of very small amounts of gold in late $1800^{\prime} s$ and early 1900's. 
(Wood R.)

Bristol Bay reglon
Mercury (?)

Dillingham

W $1 / 2$ SW $1 / 4$ quad.

Summary: Cinnabar in gravels reported. No source óf data glven; no mention of such an occurrence in any other reports, so this one 18 suspect. Occurrence may be Arcana Cr. See also (Marah Mtn.).

Malone, 1962 (IC 8131), P. 57 - Reported to carry clnnabar In gravela.

Malone, 1965 (IC 8252), p. 56 -- Reference to IC 8131. 
Allce \& Bessie

Anlak district

MF-368, Ioc. 7
Antimony, Mercury

Sleetmuce $(13.75,14.2)$

$61^{\circ} 48^{\prime} \mathrm{N}, 157^{\circ} 20^{\prime} \mathrm{W}$

Stmmary: Cretaceous graywacke and ahale 1ntruded by dikes and o111s now altered to a mixture of clay and carbonate minerals, quartz, and ifmonite; relict diabasic texture. Bedding-plane faults extend into Intrusive bodlea. Ore is clnnabar, stibntte, and pyrtte In quartz-carbonate-clay gangue in velng and vetnilets (no more than $1 \mathrm{ft}$. thick and as much as 50 ft. long) In fractured 1gneous rocks and graywacke and along faults. Debris in small tream nearby conta1ns much nat1ve mercury. D1scovered, 1906, and developed by ourface d1gglngs and several hundred feet of adit and drift. Production about 120 flasks of mercury before 1924 and posgibly a little more in early 1930's. Exploration (matnly trenching) In 1950' did not result in production, but some ore was otockp1led in trenches. Includes references to Parks unless speciflcally to Barometer.

Brooks, 1915 (B 622), p. 67 - Has been smal1 production of qu1cks1]ver [as of $1914]$.

Sitth, 1915 (B 622), P. 266 -- St1bntte present.

Smlth and Maddren, 1915 (B 622), P. 272, 274-280, 288 -- Preliminary to B 655. Brooks, 1916 (B 649), P. 45 -- Reference to and quotatton from B 622, P. $274-280$. Mertle and Harrington, 1916 (B 642), p. 259 -- Reference to B 622, p. 274-280. Smith, 1917 (B 655), p. 139-144-- D1scovered, 1906. Smal1-scale development work ever since [as of 1914]. 700 1bs. mercury produced, using small retort. Adit $200 \mathrm{ft}$. long from river bluff and several prospect pits and shafte. Country rock 18 sandstone and shale of probable Upper Cretaceous age; shattered and slickensided near mineralized area. Adit penetrates 2 dikes of altered rock that apparently was a rhyolite or dacite. Ore In shattered sedimentary rocks near dikes. One 18 mixed atibntte and clnnabar In velns and ansitamosing stringers and lenses. Mtnor pyrite appears to be of a different age. Gangue 18 varlable, but malnly quartz and siderite or ferruginoug dolomite. Some quartz crygtals in vugs have cinnabar crystals grown on them. Debris in small stream near adit mouth contalng much native mercury.

p. 147 -- Mercury mineralo near dikes.

p. 152 -- Stibnite present.

Brooks, 1918 (B 662), p. 25, 60 -- Development work continued, 1916.

Brook日, 1919 (B 666), p. 97 -- Some clnnabar has been retorted and the mercury sold to placer mlners on Seward Pentnsula.

Brooks, 1921 (B 714), p. 39-40 -- Some clnnabar has been retorted and the mercury sold to placer miners on Seward Peninsula.

Brooks and Mart1n, 1921 (B 714), p. 93-94 -- About 30 men employed, 1919.

Brooks, 1922 (B 722), P. 23, 60 -- Mtne operated, 19.20. .

Brooks, 1923 (B 739), p. 13 - Some underground work, but no product1on, 1921. Mertle, 1923 (B 739), p. 159 -- An example of dtkes and small intrustve bodies ss metallizing agents.

Mertle and Harrington, 1924 (B 754), p. 117 - Reference to B 622 [same as B 655]. Mining, 1919, but none reported for 1920 [Brooks in B 722 reported mining In 19201.

Brooks, 1925 (B 773), p. 47 -- Reference to B 622 [same as B 655]; also, gmal1 production unt11 1921. 
Solth, 1929 (B 797), p. 41 -- Smal1-8cale operation, 1926.

Smlth, 1932 (B 824), p. 79-80 -- Sma11-8cale operat1on, Including small productlon, 1929.

Sm1th, 1933 (B B36), P. 81 - Small product1on, 1930.

Smith, 1933 (B 844-A), P. 79 - 60 tons of ore mined, 1931; some retorted.

Smlth, 1934 (B 857-A), P. 74 - 35 tons of ore mined, 1932; most retorted.

Solth, 1934 (B 864-A), p. 79 -- May have been a 11ttle mining, 1933.

Mert1e, 1936 (B 864-C), P. 243-244 -- Reference to B 622 [same as B 655]; aløo, gmali intermittent production to 1933.

Smlth, 1936 (B 868-A), P. 81 - Negotlations for gtarting new developments on an enlarged seale, 1934.

Smith, 1937 (B 880-A), P. 86 - Arrangements made for large-8cale systemetic prospecting, which did not begin in 1935.

Sinth, 1938 (B 897-A), p. 97 -- Durtng 19365 men were prospecting. Development work [probably Including all since 1906] conslated of numerous open cuts and p1ts, an adit $600 \mathrm{ft}$. Iong with a drift $110 \mathrm{ft}$. long $75 \mathrm{ft}$. From face. Country rock is Upper Cretaceous (?) shale and saadstone cut by dikes and sllis that have been hydrothermally altered, largely to clayey materlal. Cinnabar, stibntte, pyrite, and chalcopyrite [only reference in which chalcopyrite is mentloned; report is therefore suspect] in dikes and wall rocks. Some very rlch bunches of Intergrown atibntte and clnnabar In lenses and vugs; lenees parallel to beddlng of sandy shale. Other prospecting in area.

Joegt1ng, 1942 (TDM 1), P. 24 -- Reference to B 655.

Smtth, 1942 (B 933-A), P. 90-91 - Legal complicatlona following death of owner (Parks) precluded negotiations for property In 1940. [Posatbly this also applies to Barometer.]

Bain, 1946 (IC 7379), p. 63 - Produced 120 flasks of mercury, 1906-23. Webber and others, 1947 (RI 4065), p. 8-9 - Reference to B 622 [same as B 655]. p. 19-23 - 2 umpatented clatms. Production, 120 flasks from 1906 to 1923, sold locally to placer gold miners. No production ofnce 1923 . Underground workings consigted of adtt $525 \mathrm{ft}$. Iong and a drift $240 \mathrm{ft}$. long on an ore zone. Also many shallow surface excavatlons. Bedrock 1a graywacke and shale with altered slli-11ke andesite intruglve bodles. AlI ore assoclated with altered andesite. 3 ore bodles; one that was mined, one on bank above adit, and one in river bed. Detall of USBM sampling program. Cady and others, 1955 (P 268), p. 65 -- Extengive biotite basalt o1l1.

p. 109-110 -- D18covered, 1906. Reglonal bedrock 1s Interbedded graywacke and shale of Kuskokwlm Gp. (Cretaceous) Intruded by sheets, 91118, and dikes of gilfca-carbonate rock and albite rhyolite. Mine has not produced since 1923. Total production of about 100 flagks came ma1niy from surface p1ts. $765 \mathrm{ft}$. of adt and drift. Ore (cInnabar and some stibnite) In zonee in and adjacent to a s111ca-carbonate s111 5-20 ft. thick and at lesst $700 \mathrm{ft}$. long; In fractures near1y perpendicular to 8111 and bedding; also dissemtnated in sill. Ore also found assoclated with a dike and in bed of Ruskokwim $R$.

Pennlngton, 1959 (IC 7941), p. 12 - Small production, reserve of Indicated ore. Jasper, 1961, P. 69-70 -- Clalms otaked, 1906. Trench1ng, an adit, and a 200-ft. crosscut durtag next 18 years; 120 flasks mercury produced for local placer miners. Underground vorkings extended to $765 \mathrm{ft}$. In 1936 . USBM trenching and sampling in 1942 disclosed 3 ore bodies. Some bedrock ground slulced clean in 1954; no discovertes. More surface work and driling, 1956; results not encouraging. Ore (cinnabar-stibntte) deposited along crose-fracture 


\section{Alice \& Bessie - Continued}

system In a s111; poot-ore movement along fractures; horizontal displacements of 5-20 ft. More str1pping and winze sunk 1n 1957.

Malone, 1962 (IC 8131), p. 7-8 -- Reference to B 655. Deposit found before World War II. Reference to RI 4065. s111s.

p. 13 -- On ME flank of an anticline. Alcered diabasic (?) d1kes and

p. 15 -- D1kes at Red Dev11, Barometer, W11118 and Park appear megascoplcalig to be about the same.

p. 34-36 - D1scovered, 1906. Production to end of 1959 est1mated at 130 flasks of mercury. Country rock 18 graywackes and shales. Cinnabar mineralization assoclated with altered andesite s111s and dikes. 3 ore zones, 1ncluding one in bed of Kuskokwlon R. Most mineralization in andesite, but some in wall rock.

Mackevett and Berg, 1963 (B 1142-G), P. G7 -- Relict diabasic textures in thin sectlons of dikes.

Malone, 1965 (IC 8252), p. 32, 41-43, 53 -- Same as IC 8131.

Salnobury and Mackevett, 1965 (B 1187), p. 2-3 -- Reference to RI 4065.

P. 11-15 -- Staked 1n 1906. By 1923 had produced and sold 120 flask of mercury for local use. Underground and aurface exploration from time to time through 1958. No recent production, but rich ore stockp1led In trenches. Bedrock 1o graywacke and ohale Intruded by oeveral dikes and sills that are extensively altered to a mixture of clay minerals, quartz, carbonate minerals, and 11montee. The 111 has crosscutting apophyses and blocky contacts that follow jolnt orlentations in the oedimentary rocks. A dike is offiet by bedding-plane faults. Ore is cinnabar, stibnite, and pyrite in quartz-carbonate-clay gangue; in fractures in brittle rock in s11 and bordering graywacke and in fractures along bedding-plane faulto that extend Into 1gaeous rocks. Ore bodtes are velos and velulets no thicker than $1 \mathrm{ft}$, and as much as $50 \mathrm{ft}$. long. Ad1t $540 \mathrm{ft}$. long wth a dr1ft $220 \mathrm{ft}$. long cut to explore hanging wall of a s111.

Berg and Cobb, 1967 (B 1246), P. 89, 92 -- Staked In 1906, developed by several hundred feet of underground workinge and shallow surface digginge. About 120 flasks of mercury produced and sold to local placer miners before 1924. Hawley and others, 1969 (C 615), P. 16, 18-19--Reference to B 1187 and analysis of sample of ore. 
Ammiline

Anlak district

MF-368, 10c. 7
Anttmony (?), Mercury

Sleetmute $(13.75,14.2)$

$61^{\circ} 48^{\prime} \mathrm{N}, 157^{\circ} 20^{\prime} \mathrm{W}$

Summary: Cinnabar in frectures in albite rhyolite that intrudes Cretaceous sedimentary rocks. Cady and others mention stibnite as a vela const1tuent on $p .70$, but not on $p .111$; reference on $p .70$ may refer to stibnite at Palrulew prospect only.

Cady and others, 1955 (P 268), p. 70 -- Quartz-stibnite-cinnobar velas cut rhyolite.

p. 111 -- Cinnabar occurs in fractures in albite rhyolite.

Salnsbury and Mackevett, 1965 (B 1187), p. 20 - Cinnabar in fractures In albite rhyolite that Intrudes sedimentary rocks of [Cretaceous] Kuskokwim Gp. Data from P 268, p. 111. 
Anlak district

MF-368, IOC. 10
Sleetmute $(13.85,13.7)$

$61^{\circ} 46^{\prime} \mathrm{N}, 157^{\circ} 20^{\prime} \mathrm{W}$

Summary: Cretaceous shale and graywacke are cut by dikes now altered to rocks made up malniy of stlica and carbonate minerals. Igneous and sedimentary rocks cut by faults parallel to bedding planes. Ore may be locallzed by dikes and faults. Cinnabar, atibnite, realgar, and orp1ment deposted along Jolnts and fractures. Several discrete ore zones. Developed by ad1t, crosscut, p1ts, and trenches. Production was 16 rlasks of mercury 1n 1938 and 1940. Some ore mined more recently during assessment work (50-75 tons in 1961, for example). See also: Allce Bessle [some of references to Parks may 1nclude Barometer], (Napamute).

Brooks, 1922 (B 722), P. 60-61 -- St1bnite-realgar lode reported to have been d1scovered, 1920. Sald to be no clnnabar. 100-ft. adit sald to have been driven. Reported by $\mathrm{Z}$. W. Parks.

Joesting, 1942 (TDM 1), p. 24 - Lode clnnabar depostt. Bain, 1946 (IC 7379), P. 63 - Mercury prospect. Webber and others, 1947 (RI 4065), P. 9-- Lode discovered, 1921.

P. 24-27 - 6 unpatented claims; same ownershtp as Allce Besste. Discovered, 1921. Explored by adit $122 \mathrm{ft}$. Iong and a crosscut. 10 flasks mercury retorted from float ore and some from a ptt in 1938. A few more flask recovered In 1930 and In 1939 and 1940 during assesament work. Bedrock malniy shale with some sandstone and graywacke. More faulting than at nelghboring prospects. Sulf1des recognized are cinnabar, stibnite, realgar, orp1ment; more arsentc than at nelghboring prospects. Altered andesite Intrusives present. Detalls of USBM trenching and sampling.

Cady and others, 1955 ( $P$ 268), p. $110-$ - Surface p1ts and $175 \mathrm{ft}$. of underground work1ngs. D1scovered, 1921. Production was 10 flasks of mercury 1n 1938 and 6 flasks in 1940. Cinnabar distributed 1rregular1y and unpredictably along bedding $j 01 n t s$ and in fault and fracture zones. Realgar and stibnite rather abundant. In shaly zone of 1nterbedded graywacke and shale; Intrublve s111ca-carbonate rock.

Jasper, 1961, p. 72-73 - D1scovered, 1921. Underground work cons1sted of 122-ft. ad1t and a crosscut. Production from float, a shallow p1t, and during assessment work was 10 flasks in 1938 and few more in 1939-40. More atripping and sampling in late 1950's. 50-75 tons of gurface ore mined, 1961. Mineralization assoclated with andesite dikes in shale, graywacke, and sandstone. Ore 18 cinnabar, otibnite, and realgar.

Malone, 1962 (IC 8131), P. 8 -- Had been found before World War II. Reference to RI 4065.

p. 13 - Altered diabasic (?) dikes and s11ls. Mine 1s on Red Devil fault (strike slip) zone.

p. 15 -- D1kes at Red Dev11, Barometer, Parke, and W1111s a11 appear megarcop1cally to be about the same.

p. 37-39 -- D1scovered, 1921. 8 flasks of mercury produced from 25 tons of ore in 1938. Small quant1t1es produced later in connection with ausesament work. Country rock largely shale. Hydrotherma11y altered intrusive rocks assoclated with mineralization. Cinnabar, stibnfte, and realgar along bedding Jolnts and in openings along faults and fracture zones, particularly near altered tntrugives. $200 \mathrm{ft}$, of adit, crosecut, and drift. 
Barometer - Continued

Reference to RI 4065 on USBM trenching and sampling. Trench1ng 1n 1957-58 found no new ore.

Malone, 1965 (IC 8252), p. 32, 38, 43, 53 -- Same as IC 8131.

Salnsbury and MacRevett, 1965 (B 1187), p. 18-19 -- Staked, 1921. Sporad1c trenching unt1 1960; also a 122-ft. adtt and a short crosgcut. 16 flasks of mercury produced, 1938 and 1940. On SW IImb of Sleetmute anticline in geologic setting almilar to that of Red Devil. Cretaceous shale and graywacke cut by altered dikes and bedding faults. Several discrete mercurybearing zones. Ore may be locallzed by Intersectlons of dikes and beddingplane faultg. Ore 1g clnnabar, atibnite, and realgar in quartz gangue.

Berg and Cobb, 1967 (B 1246), p. 92 -- D1scovered, 1921; developed by a 122-ft. adte, a crosscut, and p1ts and trenches. 16 flasks of mercury produced in 1938 and 1940 and a maller amount during more recent assessment work. 
(Cal1fornia Cr.)

Antak district

MF-368, 10c. 20
Gold

Sleetmute (11.6, 15.75) approx. $61^{\circ} 53^{\prime} \mathrm{N}, 157^{\circ} 35^{\prime} \mathrm{W}$ approx.

Sumary: A 11ttle placer gold; bedrock 1n area 1s Cretaceous graywacke and shale cut by sheets of albite rhyoltte. Geologically olmilar to Don11n Cr., Idttarod quadrangle.

Cady and others, 1955 (P 268), p. 69 -- Sheets of alb1te rhyolite cross bedding of strata [graywacke and shale of Kuskokw1m Gp. (Cretaceous)]; simllar to relations near Donlin Cr. [Id1tarod quad.]. A little placer gold has been found.

p. 120 - Ras been prospectIng. 
(Central Cr.)

Anlak district

MF-368, 10c. 19
Gold

Sleetmute $(8.8,15.7)$ approx.

$61^{\circ} 53^{\prime} \mathrm{N}, 157^{\circ} 46^{\prime} \mathrm{W}$ approx.

Summary: Some placer gold; hes been prospecting.

Cady and others, 1955 (P 268), p. 120 -- Has been prospecting. Some gold has been found; albite rhyolite intrusions abundant in general area. [Geologic map shows bedrock to be graywacke and shale of Ruskokwlm Gp. (Cretaceous) in entire dratnage bagin.] 
Cinnabar Chtef

Anlak district
Mercury

Sleetrute $(13.55,14.4)$ (?)

$61^{\circ} 49^{\prime} \mathrm{N}, 157^{\circ} 22^{\prime} \mathrm{W}(?)$

Summary: Qulcks1lver depos1t. Probably in area covered by W11l1s property.

Smlth, 1929 (B 797), p. 41 -- Qu1cks1lver deposit; prospecting or operat1ng in 1926.

Joest1ng, 1942 (TDM 1), p. 24 - Reference to B 797.

21 
Anlak digtrict

Sleetmute $(6.1-6.2,17.3-17.6)$

MP-368, 10c. 16

$61^{\circ} 59^{\circ}-62^{\circ} 00^{\prime} \mathrm{N}, 158^{\circ} 15^{\circ} \mathrm{W}$

Summary: Placer gold in benches east of creek; most of mining in part of basin in Iditarod quadrengle. See also (Donlin Cr.) Id1tarod quad. Note: Area shown as loc. 16, MF-368, posstbly should be shown as entirely east of creek.

Maddren, 1915 (B 622), p. 351-353 -- Stream 1nto wh1ch DonItn Cr. [Id1terod quad.] Flows. Most of mining in basin was near Donlin Cr. Bedrock [Cretaceous] sandstone and shale cut by all1ceous intrusive rocks. Placer gold to bench deposits east of creek; found as far downstream as mouth of Crevice Cr.

Cobb, 1973 (B 1374), p. 43 -- Mining [malnly 1n part of basin in Idicarod quad.] from 1910 to as recently as 1956 . 
(Egnaty Cr.)

Anlak distrlet

MF-368, loc. 3
Mercury

Sleetmute $(9.4,15.2)$

$61^{\circ} 52^{\prime} \mathrm{N}, 157^{\circ} 52^{\prime} \mathrm{W}$

Summary: USBM exploration program in 1966-67 found a little very fine-grained ctnnabar in Cretaceous sandstone and graywacke and somewhat more in the overlying soll. No Igneous rocks found near prospect.

Maloney, 1968 (USBM OF 16-68)- In 1966-67 the USBM carrled out an explorat1on program of augex sampling material above bedrock, bulldozer trenching, dlamond drilling, and soll sampling. Bedrock 1s Cretaceous sandstone, graywacke, and minor shale. No 1gneous rocks were found near the prospect. CInnabar was found in few places in the exposed bedrock, but could be paned from samples taken from overburden in trench walls and from about 100 of the 350 auger holes. Selected samples of sandstone and graywacke bedrock assayed almost 1 percent $\mathrm{Hg}$; $\mathrm{As}$ and Sb were found only in trace amounts. No mineralization found in shale beds. Some drill-hole samples contalned very fine-grained clnnabar. 
(E1ghtm1le $\left.C r_{0}\right)$

Anlak district

MF-368, loc. 21
Gold

Sleetmute (11.7, 14.0) approx.

$61^{\circ} 47^{\prime} \mathrm{N}, 157^{\circ} 36^{\prime} \mathrm{W}$ approx.

Sumbry: Has been prospecting; some placer gold pregent.

Cady and others, 1955 (P 268), P. 120 -- Has been prospecting; some placer gold present; albite rhyolite intruslons in general area. [Geologlc map shows small albite rhyolite bodies on divides; rest of bedrock 18 all Cretaceous graywacke and shale of Kuskokwlm Gp.] 
Falrview

Anlak district

MF-368, Ioc, 8
Antimony, Mercury

Sleetmute $(13.55,13.65)$

$61^{\circ} 46^{\mathrm{N}} \mathrm{N}, 157^{\circ} 22^{\circ} \mathrm{W}$

Summary: Staked in 1935 or 1936. Only work was excavation of surface pits and trenches. Porphyr1t1c alb1te rhyol1te $\mathrm{B} 111$, about $120 \mathrm{ft}$. thlck, 1ntruded Cretaceous graywacke and shale. Clanabar and stibntte veinlets in fractures in central part of a111. Some USBM samples contalned as much as 8 Ibs. mercury per ton of rock, but most were much leaner.

Ba1n, 1946 (IC 7379), p. 63 -- Mercury prospect.

Webber and others, 1947 (RI 4065), p. 27-28 -- F1rst staked in 1935 or 1936. Shale and sandstone 1ntruded by fresh-appearing rhyollte dike. Cinnabar and stibnite mineralization localized by intersection of fracture zone and d1ke. USBM trenchlng found some samples whth 8 1bs. mercury per ton of rock, but most were much leaner.

Cady and others, 1955 (P 268), P. 70 -- Quartz-st1bnite-cinnabar velns cut rhyoI1te.

p. 111 -- A few ourface p1tg and trenches. Cinnabar-stibnite velnlets In fractures in central part of porphyritic albite rhyolite o11I (about $120 \mathrm{ft}$. th1ck) in interbedded graywacke and shale.

Malone, 1962 (IC 8131), p. 8 -- D1scovered before World War II.

P. 38 - Same data as In P 268, P. 111.[not c1ted]. Also reference to RI 4065.

Malone, 1965 (IC 8252), P. 32, 39, 53 -- Same as IC 8131.

Sainsbury and Mackevett, 1965 (B 1187), p. 19-20 - Data from P 268 and RI 4065. 
(Fortyseven Cr.)

Antak district

MP-368, 10c8. 15, 18
Ant1mony, Gold, S1lver, Tungsten

Sleetmute $(6.95-7.3,0.75-1.0)$

$61^{\circ} 02^{\prime}-61^{\circ} 03^{\prime} \mathrm{N}, 158^{\circ} 08^{\prime}-158^{\circ} 11^{\prime} \mathrm{W}$

Sumbary: A silicifled shear zone in Cretaceous graywacke and shale at head of creek contalns quartz velng with gold, scheelite, wolframite, arsenopyrtte, famesontte, atibnite, argent1te, traces of gold and silver tellurtdes, and tourmaline and serfclte. Placer deposit below shear zone has been mined, wth both gold and scheellte recovered and sold. Stream crosses major fault at foot of mountain. Below fault placers developed on bedrock and on false bedrock of yellow clay.

Cady and others, 1955 (P 268), p. 119-121 -- Bedrock 1s graywacke and shale of the Cretaceous Ruskokwim Gp. A shear zone In the ridge at the head of the creek 18 siliclfled and contains much vein quartz; $1,000 \mathrm{ft}$. wide and $1-1 / 2$ mi. long. Metalite minerals include gold, scheelite, wolframite, arsenopyrite, Jamesonite, stibnite, argentite, and traces of gold-ollver tellurldes; quartz to chlef gangue mineral and is accompanted by tourmaline and serlclte. A placer deposit Immediately downstream from the shear zone has been mined, with gold and scheelite mined and sold. A fault marke the base of the mountain front; below 1 there are 2 types of placers. One 1s on bedrock, with a little gold scattered in the werlying gravel; the other 18 on a yellow clay false bedrock where gold and scheelite are concentrated. Depth to bedrock Increages rapldiy below fault. Deposits discovered In 1947.

Berg and Cobb, 1967 (B 1246), p. 93 -- Shear zone In graywacke and slate contalns quartz velns carrying small amounts of natlve gold, scheelite, wolframite, arsenopyrite, Jamesonfte, stibntte, argentite, and traces of gold-silver tellurides. No record of production, but gold and scheelite have been recovered from placers.

Eakins, 1968 (GC 17), P. 8 -- Tungsten has been mined.

Cabb, 1973 (B 1374), P. 43 - Gold and scheellte have been mined from placers below a scheeltte- and gold-bearing lode in a sllclfled shear zone in graywacke and shale. 
(Fuller Cr.)

Aniak district

MF-368, 1oc. 22
Gold

Sleetmute (13.1, 13.4) approx. $61^{\circ} 45^{\prime} \mathrm{N}, 157^{\circ} 26^{\circ} \mathrm{W}$ approx.

Summary: Placer gold present; has been prospected.

Cady and others, 1955 (P 268), P. 120 -- Placer gold present; has been prospecting. Albite rhyolite Intrusions abundant in area. [Geologic map shows bedrock as Cretaceous graywacke and shale of Ruskokwlm Gp. with several large albite rhyollte intrustve bodieg across upper part of valley.] 
(George R.)

Anlak district
Gold, Mercury

Sleetmute $(10.5-10.85,16.1-16.2)$ $61^{\circ} 55^{\prime} \mathrm{N}, 157^{\circ} 41^{\prime}-157^{\circ} 43^{\prime} \mathrm{W}$

Summary: Bars carry very fine colors of gold and conslderable fine cinnabar.

Maloney, 1969 (USBM OF 16-69) - Bar sediments contain very fine (requires hand lens to see) gold and fine cinnabar. 
(GIrI Cr.)

Anlak district
Gold

Sleetmute $(5.0,4.5)$ approx. $61^{\circ} 15^{\prime} \mathrm{N}, 158^{\circ} 25^{\circ} \mathrm{W}$ approx.

Summary: Placer gold present; has been prospecting.

Cady and others, 1955 ( $P$ 268), P. 120 -- Gold present; has been prospecting. Albt te rhyolite intrusions in area. [Geologic map shows basin to be underlain by Cretaceous graywacke and shale of Ruskokwim Gp. Intruded by small bodies of albite rhyolite and quartz diabase.] 
(Gold Run)

Anfak district
Gold

Sleetmute $(4.5,7.5)$ approx. $61^{\circ} 25^{\prime} \mathrm{N}, 158^{\circ} 28^{\prime} \mathrm{W}$ approx.

Sumary: Placer gold present; has been prospecting.

Cady and others, 1955 (P 268), p. 120 - Placer gold present; has been prospecting. Albite rhyolite bodies in area. [Geologic map 1ndicates that basin 1s underlatn by Cretaceous graywacke and shale of Kuskokwim Gp.; small Intrualve bodies of albite rhyolite.] 
Harvison

Anlak district

MF-368, 1oc. 4
Mercury

Sleetmute $(11.45,17.05)$

$61^{\circ} 58^{\prime} \mathrm{N}, 157^{\circ} 37^{\prime} \mathrm{W}$

Sumary: Small lenses or pods of clnnabar in brecciated silicifled shaly sandstone Intruded by a now-altered dike or a11. Exploration, in 1963, by shallow strlppling and trenching.

Jasper, 1963 - Discovered about 1963 by panning soll samples. Bedrock 1s slightly sillclfled sandstone; cut by weathered and oxtdized dike (or si11?). Cinnabar in volda in a breccia zone and in velniets along fractures. No stibntte was noted. Exploration cons1sted (in 1963) of a trench and a 3-1/2 foot "wlaze."

Berg and Cobb, 1967 (B 1246), p. 92 -- Small lenses or pods of clanabar In brecclated silfcifled shaly sandstone cut by a dike or s1ll similar to one exposed at Alice and Bessle mine. Deposit discovered by soll sampling followed by shallow gtripping and trench 1 g. 
(Holltas R.)

Anlak dfstrict
Gold

sleetmute

S. central part of quad. (?)

Summary: Very flue colors of gold have been found in river bars near mouth. All other references are to vague reports of placer gold in basin; no better data on location; may apply to tributarles in Taylor Mts. quad.

Martin, 1919 (B 692), p. 40 -- Prospecting reported to have ylelded encouraglng results, 1917.

Brooks, 1922 (B 722), p. 60 -- Dri111ng of prospective dredging ground reported, 1920.

Smith, 1934 (B 864-A), p. 45-46 -- Some placer gold reported to have been found in winter of 1932-33 and clalms staked. No detalls on supposed find; not even the approximate location.

Sm1th, 1936 (B 868-A), P. 46 -- About the same as B 864-A, except that winter of 1933-34 1s mentloned.

Smith, 1937 (B 880-A), P. 49 - Prospecting, 1935.

Smith, 1938 (B 897-A), P. 58 -- Have been repeated reports of rlch placer ground that 18 reportedly too wet to prospect by ordinary hand methoda.

Stoith, 1939 (B 910-A), P. 60-61 -- Same as B 897-A, P. 58.

Solth, 1939 (B 917-A), P. 59-60 -- Same as B 897-A, P. 58; may be prospect drilling in the future.

Maloney, 1969 (DSBM OF 16-69) -- Very fine colors of gold in river bars near mouth. 
(Horn Mtg.)

Aniak district
Tungsten (?)

Sleetmate

B $1 / 2 \mathrm{NW} 1 / 4$ quad.

Sumarg: Placer acheelfce reported near weat foot of mountalns.

Cady and others, 1955 (P 268), P. I21 - Plecer scheelite reported near west foot of Horn Mts. [Geologic map shows Horn Mts. as largely fault bounded mass with core a quartz monzonte pluton largely ourrounded by rhyolitic and basaltic volcantc rocks, all of Tertlary age. 0lder rocks are Cretaceous graywacke and shale of Ruskokwlm Gp.; contact metamorphosed at one place where not in fault contact with quartz monzonite and basalt.] 
(Ray Cr.)

Anlak district
Antimony (?)

Sleetmute $(2.5,5.5)$ approx.

$61^{\circ} 18^{\prime} \mathrm{N}, 158^{\circ} 42^{\prime} \mathrm{W}$ approx.

Summary: Anttmony reported.

Cady and others, 1955 (P 268), P. 122 -- Natives report antimony local1t1es. 
Anlak district MF-368, 10c. 1
Sleetmute $(0.4,10.5)$

$61^{\circ} 36^{\circ} \mathrm{N}, 158^{\circ} 57^{\prime} \mathrm{W}$

Summary: Cretaceous graywacke and shale 1atruded by a B111 25 ft. thick and. other omaller bodles of rock now altered to allica and carbonate (and probably clay) minerala. Rocke sheared parallel to bedding. Cinnabar (wthout accompanylng atibntte) in narrow stringere and disgeminations in fractures and brecclated zones in sill and enclosing rocks. First cinnabar discovery in Alaska (about 1838). Explored by extensive trenching and a short (now caved) adit. Production conglsted of a small shipment of ore in $1890^{\prime} \mathrm{s}$ and about 2 flasks of mercury in about 1910. Recent exploration did not find more ore.

Spurr, 1900, p. 261-262 -- Veln of clnnabar 10 shale where cut by g111ceous yellowlsh-weathering dikes. Mineralfzed rock in a pinching irregular zone a foot or two wlde. A I1ttle ore mined and shipped out before 1898 . but miner (LInd) lost money on the venture.

Brooks, 1911 (B 480), P. 93 -- Reference to Spurr, 1900.

Smlth and Maddren, 1915 (B 622), p. 272-274 -- Deposits in general area known before 1884. Quotation from Spurr, 1900. Statement that Spurr did not notice deposit, but got information in Bethel from Lind [see above].

p. 280-286 - Bedrock is a great thickness of shale and sandstones (some quartzoge and some arkosic) cut by many sills (many of which follow a bedding plane for a distance and then cross to another) and fewer dikes. S11ls are altered andeglte of varlous kinds; in thicker sill small crystals of clmabar are near inclusions of shale; posalble genetic olgniflcance? Next to, but not in, a smaller sill are quartz-cinnabar lenses. Very $11 t-$ tle development and very ilttle ore in sight.

Joesting, 1942 (TDM 1), p. 24 - Reference to B 622.

Webber and others, 1947 (RI 4065), p. 49-50-- 2 cla1ms. Sandstone and shale Intruded by rhyolite dikes and sills. USBM hand trenching ahowed clnnabar in a stringer in a rhyolite sill, in a shear zone parallel to the sill, and in cross fractures between the shear zone and the 8111 .

Cady and others, 1955 ( $P$ 268), $P .116$-- Cinnabar in bluffs of Kuskokwlm $R$. known by Russtans as early as 1838. Only production was about 2 flasks of mercury in 1909 or 1910. Interbedded graywacke and shale of Ruskokwm Gp. (Cretaceous) intruded by a si11 of sillca-carbonate rock 25-30 ft. thick and other gmaller bodies. Shear zones parallel bedding; 1rreguler fractures and breccla zones at or near upper contact of large sill. Cinnabar (no stibnite) in quartz gangue in brecclated zones and diseminated in s1l1ca-carbonate rock and adjacent graywacke.

Jasper, 1961, p. 67-68 -- F1rat cinnabar occurrence known to whyte nen In Alaska. Small ore shipment made before 1898. More work In early 1900'B; 2 Elasks produced. USBM trenching and sampling, 1944. Rurther trenching and stripping, 1954. Ore in sheared shale and sandotone near a rhyolite sill. Cinnabar (only sulfide mineral) in short stringers and velnlets, omall lenses, and pode.

Malone, 1962 (IC 8131), p. 7-8 - References to Spurr, 1900; and RI 4065.

p. 33-34 -- References to Spurr, 1900; Swith and Maddren, 1914 (B 622), and RI 4065. More USBM sampling, 1958.

Malone, 1965 (IC 8252), p. 32, 39-40, 53 - Same as IC 8131. 
(Kolmakof) - Continued

Sa1nsbury and Mackevett, 1965 (B 1187), p. 49-50 - Russtans probably were aware of deposit as early as 1838. Exploratory workfngs consisted of a caved adit and shaft, 29 hand-dug trenches, and a few bulldozed trenches (that did not reach bedrock) (as of 1959). Only production was about 2 flaskg of mercury in 1909 or 1910. Rest of data from P 268 and RI 4065.

Berg and Cobb, 1967 (B 1246), p. 92 -- S1te of firgt cinnabar discovery in Alaska (about 1838). Altered s1ll $25 \mathrm{ft}$. thlck In graywacke and shale exposed for horfzontal distance of about $400 \mathrm{ft}$. Cinnabar ta narrow atringers in sill and enclosing sedimentary rocks. Stripping in 1954 did not reveal a minable ore body. Small shipment of ore In $1890^{\prime} \mathrm{g}$ and 2 flasks of mercury produced in about 1910.

Merr111 and Maloney, 1974 (DSBM OF 21-75) - In 1969 and 1970 the USBM attempted to delineate posalble extensions of the known mercury deposit or other deposits in the 1mmediate vicinity by sampling auger holes and in bulldozed trenches. The attempt was not successful, possibly because of the heavy moss and loess overburden. 
(Kuskokw1m R.)

Anlak district
Gold

Sleetmute $(7.7-15.3,13.0-15.25)$

$61^{\circ} 44^{\prime}-61^{\circ} 54^{\prime} \mathrm{N}, 157^{\circ} 09^{\prime}-158^{\circ} 04^{\prime} \mathrm{W}$

Summary: Very flae colors of gold in bar sediments.

Maloney, 1969 (USBM OF 16-69) - R1ver bar sediments contaln very fine (requires hand leng to see) gold. 
Landru

Anlak diatrict

MF-368, 1oc. 13
Meronty

Sleetmute (15.1, 12.6) approx.

$61^{\circ} 42^{\prime} \mathrm{N}, 157^{\circ} 11^{\prime} \mathrm{W}$ approx.

Summary: RIch clnnabar float; not traced to bedrock source.

Joesting, 1942 (TDM 1), p. 23-24 - R1ch clnnabar float; not traced to source. Area said to be geologically bintlar to Red Devil. 
(McCally Cr.)

Ariak district

MF-368, loc. 12
Mercury

Sleetmute $(13.75,13.0)$ approx. $61^{\circ} 44^{\prime} \mathrm{N}, 157^{\circ} 21^{\prime} \mathrm{W}$ approx.

Sumary: Traces of clnabar in Cretaceous graywacke and shale near contact wth albite rhyollte near head of creek. Native mercury reported to have been panned from creek.

Cady and others, 1955 (P 268), P. 111 -- Traces of cinnabar at elevation of about 1,000 ft. on slope of Barometer Mtn. near head of McCally Cr. In [Cretaceous] graywacke and shale [of Kubkokwim Gp.] near contact with porphyritic albite rhyolite.

Jasper, 1961 , p. 75 -- Native mercury reported to have been panned from creek. Salnsbury and Mackevett, 1965 (B 1187), p. 21 -- Reference to P 268, p. 111. 
(Mellick's)

Anfak district

MF-368, loc. 14
Mercury

Sleetroute $(15.05,12.3)$

$61^{\circ} 41^{\prime} \mathrm{N}, 157^{\circ} 11^{\prime} \mathrm{W}$

Sumary: Smell amount of clmnabar in bedrock.

Cady and others, 1955 (P 268), p. 111 - Small amount of cinnabar in bedrock back of Meilick's trading post. [Geolog1c map shows Cretaceous graywacke and shale of Ruskokwlm Gp. and several omall albite rhyolfte 1ntrualons.] Salnsbury and Mackevett, 1965 (B 1187), p. 21 - Reference to P 268, P. 111. 
Mercury

Aniak district

MF-368, Ioc. I1
Antimony (?), Mercury

Sleetmute $(13.95,13.55)$

$61^{\circ} 46^{\prime} \mathrm{N}, 157^{\circ} 19^{\prime} \mathrm{W}$

Summary: Clnnabar (and possibly atibntte) in stringers along bedding planes of shale.

Cady and others, 1968 (P 268), p. 111 -- Clatm between Red Dev11 and Barometer mines. Ore minerals [assumed to be cinnabar and possibly stibnite] as bedding stringers in shaly zone of 1nterbedded graywacke and shale [of Cretaceous Kuskokwim GP.].

Safnsbury and Mackevett, 1965 (B 1187), p. 20 -- Cinnabar as stringers along bedding planes of shale; reference to $P 268$, p. 111. 
Mountaln Top

Anfak district
Antimony, Mercury

Sleetmute $(8.75,7.0)$

$61^{\circ} 24^{\circ} \mathrm{N}, 157^{\circ} 58^{\mathrm{i}} \mathrm{W}$

Summary: D1scovered in 1968. Cinnabar in vains near or along slip surfaces of faults that cut basaltic dikes now largely altered to sil1cadolonfte-clay minerals - "Iddingsite" rock. Dikes cut Cretaceous graywacke and shale. St1bnite in float fragments and as crystal aggregates in quartz velnletg. Explored by trenching and drilling. Reserves in sight amount to 200 flasks of mercury.

Sorg and Estlund, 1972 (MF-449) -- Discovered in 1968 by panning stream oed1ments of Chineekluk $\mathrm{Cr}$. and Oskawallk $\mathrm{R}$, and following detrital cinnabar to bedrock source. Flve cinnabar velns exposed by tranching. Seven drill holes put down by USBM In 1970. One ton of high-grade residual cinnabar recovered and stockplled during exploration. Reserves in sight estimated at 200 flasks of mercury. Interbedded Cretaceous graywacke and shale of Ruskokw1m Gp. Intruded by faulted, pervasively altered olivine basalt dike. Sedimentary rocks intensely altered near dikes; most highly altered dikes now almost completely changed to cryptocrystalline s1lica. Near faults basalt is brecclated and consists mainly of "Iddingstte," quartz, dolomite, and clay minerals. Cinnabar in veins (1) within $6 \mathrm{In}$. of fault s11p surfaces with much dolomite and (2) along slip surfaces and without dolomite. Stibnite found only as deeply weathered float fragments and as cryotal aggregates in small quartz velalets. 
(Murray Gulch)

Anlak district

$M F-368$, loc. 17
Gold

Sleetrute $(3.3-3.5,9.8-10.0)$

$61^{\circ} 34^{\prime} \mathrm{N}, 158^{\circ} 35^{\prime}-158^{\circ} 36^{\prime} \mathrm{W}$

Sumary: Interbedded sanditone (or graywacke) and shale Intruded by felsic dikes in upper part of gulch. Velns and lentfcular stringers of quartz and calcite along borders of dikes and in jolnts and shear zones In wall rock. Stream placers frozen and $35 \mathrm{ft}$. deep at mouth; less upstream. Two levels of bedrock benches with aurfferous gravel. Discovered in 1910 and mined sporadically on a small scale for 10 or more years. Includes references to (Mary $\mathrm{Cr}_{.}$); see also (New York Cr.).

Maddren, 1915 (B 622), p. 353-355 -- Placer gold discovered, 1910; coarse gold In deep gravels beneath gtream and in bench gravels on both sides of valley. Country rock is steeply dipplng Interbedded sandstone and shale intruded by siliceous dikes one to more than $3 \mathrm{ft}$. thick. Velns and lenticular atringers of quartz and calcite along borders of dikes and in joints and shear zones in wall rock. Dikes cross Murray Gulch about a mile above mouth. Stream grave1s $35 \mathrm{ft}$. deep at mouth and less upstream; most are frozen; dr1ft minlag, 1914. Two levels of bedrock benches on left slope of gulch are covered with gravel contalning coarse unworn gold; prospectIng, 1914 .

Brooks, 1918 (B 662), p. 61 - Mining on Mary Cr., 1916. [Th1s 1nformation must be confused, as reference states that this 18 f1rst production, which is at varlance with Maddren's description (B 622).]

Brooks, 1922 (B 722), P. 60 - Gold mined on Mary Cr., 1920.

Cady and others, 1955 (P 268), p. 119 -- Gold dlscovered, 1910. M1ned sporadically since then; total productlon worth only a few thousand dollars. Bedrock 1s Interbedded graywacke and shale; rhyollte dikes acrose upper part of gulch; all gold downstream from d1kes. Stream gravels under silt and muck. Reference to B 622, P. 355.

Cobb, 1973 (B 1374), P. 43 -- Area geologically similar to that near Donlin and Jullan Creeks [Id1tarod quad.]. Has been mintng. 
(Napamute)

Anlak district
Mercury

Sleetmute (13.85, 13.7)

$61^{\circ} 46^{\mathrm{N}} \mathrm{N}, 157^{\circ} 20^{\circ} \mathrm{W}$

Summary: Minfag, 1925. Th1s occurrence may be the same as the Barometer. See also Barometer.

Mofflt, 1927 (B 792), p. 33-34 - Ten tons of clnnabar ore mined in 1925; not retorted.

JoestIng, $1942, ; p .24$-- Reference to B 792, p. 33. 
(New York Cr.)

Anlak distrlct

MF-368, 10c. 17
Gold

Sleetmute $(3.5,10.0)$

$61^{\circ} 34^{\prime} \mathrm{N}, 158^{\circ} 35^{\prime} \mathrm{W}$

Sumary: Sporadic small-scale mining at mouth of Murray Gulch from 1914 to about 1920. See also (Murray Gulch).

Maddren, 1915 (B 622), P. 304 -- Gold prospects belng developed tn basin, 1914. 1914.

p. 353 -- Gold in gravels at mouth of Murray Gulch. Prospecting,

Brooks, 1916 (B 642), p. 68 -- Mining, 1915.

Brooks, 1918 (B 662), p. 60-61 - Hydraul1c plant Installed, 1916.

Brooks, 1922 (B 722), p. 60 -- Mining, 1920.

Cady and others, 1955 (P 268), p. 119 -- Mining at mouth of Murray Gulch. Small sporadic production. For data on regional geology see (Murray Gulch).

Cobb, 1973 (B 1374), P. 43 - Has been minfing. Geologically glmtlar to area near Donlin and Jullan Creeks [Idltarod quad.]. 
Arlak district

Sleetmute

$\mathrm{SE} 1 / 4 \mathrm{SE} 1 / 4 \mathrm{NW} 1 / 4$ quad.

Sumary: Some placer gold; has been prospecting near Henderson Mtn., which is a small quartz moazonfte stock.

Cady and others, 1955 (P 268), P, 120 -- Placer gold present; has been progpecting near Henderson Mtn.; alblte rhyoltte 1ntruslons in area. [Geologlc míp shows bedrock as Cretaceous graywacke and shale of Kuskokwlm Gp. Many small bodies of albite rhyolite and quartz diabase. Henderson Mtn. is small quartz monzonite stock surrounded by hornfels zone as much as about 1-1/2 m1. wide.] 
Red Dev11

Anlak district

MF-368, 10c. 11
Antimony, Mercury

Sleetmute $(13.95,13.55)$

$61^{\circ} 46^{\circ} \mathrm{N}, 157^{\circ} 19^{\circ} \mathrm{W}$

Summary: Cretaceous graywacke and argillaceous rocks were intruded by probably diabasic dikes that are now altered to rocks consisting malniy of quartz and carbonate and clay minerals. All rocks are cut by faults most of which are parallel to bedding. Ore is cinnabar, stibnite (generally in amounts equal to or 8 reater than cinnabar), and minor realgar and orplment. Most ore bodles were locallzed at Intersections of dikes and bedding-plane faults and are crudely prismatic. The range in thickness from a few Inches to $4 \mathrm{ft.,}$ are elongate (a few to several hundred feet long), and plunge southward. Most were formed by open-space filling; a few by replacement of dike rock. Deposits in zone at least $600 \mathrm{ft}$. wide and 1,500 ft. long. Alaska's largest (and a major U.S.) mercury mine. Discovered 1n 1933; most development was since World War II. Worklags aggregate about 9,600 ft. on 5 maln levele. Production through 1962 was 31,718 flasks of mercury, 28,765 of which was from 1950 to 1962. A small amount of antimony also was sold [to Japan as soot], but most was not saved; stlbnte interfered with mercury recovery.

Joesting, 1942 (TDM 1), p. 21, 23-24 -- On1y property produclng mercury in 81galficant amounts in 1941. Production was 167 flasks in 1940 and 80 flasks In 1941 to Sept. 15. Cinnabar occurs as stringers tn large lenses in a shear zone in sandstone and shale. Stlbalte wlth cinnabar. Metacinnabar abundant at surface. Rhyollte dikes apparently assoclated with minerallzation.

Swth, 1942 (B 933-A), P. 90 -- Considerable development, 1940. Bnough ore taken out to keep 2 retorts (capaclty 1 ton per day each) busy for nearly 3 months.

Joesting, 1943 (TDM 2), p. 17 - Mercury produced, 1941. Several minable bodies opened. Depostts said to be larger, but lower grade, than at DeCourcy [Iditarod quad.].

Ba1n, 1946 (IC 7379), p. 63 -- Est1mates in March 1943 suggested 11,360 tons of material contalning $45.3 \mathrm{lbs}$. $\mathrm{Hg}$ per ton and 15,900 tons contalning 36.7 1bs. Production 1944-45 was 2,060 flasks. About equal amounts of mercury and antimony in ore.

Webber and others, 1947 (RI 4065), p. 3 -- Production, 1933-42, from mined and float materlal, was 419 flasks of mercury. USBM exploration program 1942-43.

p. 9-18 - Found in 1933 by tracing flost found in small stream bed. Property is 9 unpatented claims. Several hundred feet of adits and crosscuts. In 1944-45 2,052 flasks was produced from 4,166 tons of ore. Detalls of USBM exploration (surface and subsurface) and sampling, 1942-43. Bedrock Is shale with lnterbedded sandstone and graywacke and andesite s1lis. Ore (clnnabar and etfbnite) princlpally along hanglng-wall contacts of sils. Data on retorting and finances.

Cady and others, 1955 (P 268), P. 65 -- Altered blotite basalt (allica-carbonate rock) in echelon syatems of $8111 \mathrm{~s}$ and sill-11ke bodies connected localiy by dikes on SW limb of syncline; follow faint flexures in sedimentary rocks. p. 108-110 - Yield of metallurglcal plant low because of high antimony content of ore. When mine shut down in 1946 there were 2 adit levels, 2 shaft levels, 2,000 ft. of drifts and crosscuts, and 20 stopes. Bedrock 
Red Devil - Continued

Is graywacke and shale [of Kuskokwim Gp. of Cretaceous age] on SW limb of Sleetmute anticline. Workings in zone at least $250 \mathrm{ft}$. thick (chlefly shale) with s1lica-carbonate $8111 \mathrm{~s}$ and s111-l1ke bodies. Ore (cinnabar-stibntte) commonly on hanglng-wall borders of sills (some thin sills completely replaced by stfbatte) and beyond upper ends of s111s along bedding. One ore body follows \& dike. Some ore zones contaln more gtibnte than clnnabar. Production [deternfoed by adding amounts 11sted] was about 3,060 flasks of mercury from 4 of 6 ore zones.

Pennington, 1959 (IC 7941), p. 12 - Interbedded Cretaceour graywacke and shale cut by sills and dikes of hydrothermally altered blotite basalt. Ore in irregular veins and velnlets in fault zones and at contacts between alliclfled basalt and graywacke. Much stibnite with cinnabar in quartz gangue; calcite, realgar, and orplment also present. Measured reserve 1s over 10,000 flasks in ore averaging $15 \mathrm{lbs}$, per ton and 3,000 flasks in ore averaging $40 \mathrm{Ibs}$. per ton. Additional ore can be inferred. 1954.

P. 52 -- Plant, camp bulldings, and mill degtroyed by fire, October

P. 85 -- Had DMRA contract.

Chapman and Shacklette, 1960 (P 400-B), p. B105 -- As, Sb, and $\mathrm{Hg}$ anomalous in soll samples.

SaInsbury and Mackevett, 1960 (P 400-B), P. B35 -- Has produced more than 20,000 flesks of mercury. Mine in graywacke and argillaceous rocks of Cretaceous Kuskokw1m $\mathrm{Gp}$, and in altered dikes that cut them. Ore bodies at and near Intersectlons between $\mathrm{NE}-t r e n d 1 \mathrm{ng}$ dikes and NW-trending faults that are esientially parallel to bedding. Ore bodles pencll shaped.

Jasper, 1961, p. 73-75 -- Discovered, 1933. Residual materlal retorted before 1940; 11 flasks recovered. Bedrock materlal exposed by ground-glule1ng in 1940-42 ylelded 410 flasks. Underground workIngs begun, 1940. Data from RI 4065 for perlod 1942-46, when production was 500 flasks. Assessment work only unt11 1952. Production 1953-61 was nearly 25,000 flasks. Ore shoots associated with andesite dike fragments in echelon pattern along beddlng plane faults. Ore grade tends to fall off with depth. Ore 18 cinnabar and otibnite with rare realgar, pyrite, and arsenopyrite.

Malone, 1962 (IC 8131), p. 2 -- One of principal mercury producers in Alaska; major production durfing and Immediately after World War II and after 1954.

p. 8 -- Discovered before World War II; reference to RI 4065.

p. 11-33 -- Stibnite has caused difficulty in retorting the ore. Deposit discovered, 1933. Exploration and mining unt11 1946 (production data given are not complete]. Mine reopened, 1952. Fire damage halted operatlons from late 1954 to early 1956. Production, 1940-59 was 19,530 flasks 【15,486 after March, 1956). Bedrock 1s Upper Cretaceous graywacke and mudstone folded Into the Sleetmute anticline and cut by the Red Devil strikeslip right-lateral fault. Altered diabagic (?) dikes and sills. Ore shoots along Red Devil fault or along subsidiary olips in footwall. Me is on SW flank of Sleetmute ant1cline. 2 sets of foints perpendicular to bedding. 3 dikes of dlabasic rock altered to quartz, chalcedony, carbonate, and sericlte. Red Devil and subsldiary bedding faults have offset dike gegments $800 \mathrm{ft}$. Ore localized at Intersectlons of bedding plane faults and dikes; ore bodles pencll shaped. Other ore bodies along faults connecting bedding-plane faults. Ore 1s clnnabar and stibnite with local small amounts of realgar and orplment and rare pyrite films on joint 
Red Devil - Continued

surfaces; gangue malnly quartz and clay. Stlbnite-cinnabar ratio increases with depth and with width of ore shoots. Ore shoots surrounded by halos of quartz, clay, and cinnabar. Ore probably formed no earller than late Miocene. [Pages 20-33 are detalls of mining methods, costs, and metallurgy.]

Mackevett and Berg, 1963 (B 1142-G):-- Clatms orlginally staked, 1933. Praduction, 1939-46 and 1952-59, was about 20,000 flasks of mercury. About 9,600 ft. of underground workings on 5 main levels. Sedimentary rocks are about 1,300 ft. of graywacke and argillaceous rocks of Cretaceous Ruskokwim Gp. Three hydrothermally altered dikes varying in thickness from 1 to $14 \mathrm{ft}$. exposed in mine area. Dikes have relict porphyritic texture and consist entirely of fine- and very fine-gralned calcite, chalcedony, 11monite, and serlcite with subordinate quartz, hematite, and clay minerals (ailicacarbonate rock of Cady and others, 1955 (P 268)). Mine is on SW limb of NW-trending Sleetmute anticline. The dominant faults strike NW and commonly are parallel to bedding; minor gouge and breccla; contorted and plicated argillite in zones up to $10 \mathrm{ft}$. thick. Individual faults cannot be traced far; are in en echelon pattem. A few faults transect bedding. Movement mainly rlght lateral; cumulative displacement of several hundred feet. Very few transverse faults. Ore in many diacrete bodies malnly localized along and near Intersectlons of NE-trending altered dikes and NW-trending faults; crudely prismatic in shape; range from a few Inches to $2 \mathrm{ft}$. thick and 1-30 ft. In strike length; severa1 hundred feet in plunge direction. Some ore very $\mathrm{HCh}(30 \% \mathrm{Hg})$, but most contains $2-5$ percent $\mathrm{Hg}$. Larger and richer bodles in and near dikes. They grade outward Into networks of closely spaced clnnabar velns, then into widely spaced velnlets In protore with less than $1 \% \mathrm{Hg}$. Most ore formed by open-space filling; some probably partlally formed by replacement. High-grade ore is intimately assoclated cinnabar and stibnite. Ore also contains some realgar, orpiment, secondary antimony minerals, and minor tron minerals. Quartz, carbonate, and clay gangue. Ore probably late Mtocene or early Pllacene, of hydrothermal origin, and younger than most of faults.

Balley and Swith, 1964 (C 496), p. 2 -- Ore contalns more antimony than mercury; no antimony recovered.

p. 9-10 -- Total production through 1962 was 31,718 flasks; product1on 1950-62 was 28,765 flasks; not operating in 1964.

U.S. Geologlcal Survey, 1964 (P 501-A), P. A5 -- Summary of B 1142-G.

Malone, 1965 (IC 8252), P. 31-33, 42-45, 53 -- Data from IC 8131.

SaInsbury and Mackevett, 1965 (B 1187), p. 2-3 -- Produced more than 20,000 flasks of mercury by 1960. RIch ore discovered (w1th DMEA 1oan); In 1957 mine became one of the largest producers of mercury in the U.S. By 1964 known ore bodtes had been exhausted; new exploration falled to find ore. By late 1964 all production was by small leasers.

p. 8-11 -- Summary of date from P 268 and B 1142-G.

p. 81 - Semiquantitative spectrographic analyses of samples.

Berg and Cobb, 1967 (B 1246), P. 89 -- Graywacke and shale intruded by altered dlabasłc dikes consisting of allica, carbonate, and clay minerals. Rocks cut by many faults parallel to bedding. Ore bodies which consist of massive aggregates and encrustations of quartz, clay, calclte, cinnabar, stibnite, and minor realgar and orplment, formed near intersections of dikes and faults in a zone at least $600 \mathrm{ft}$. wlde and $1,500 \mathrm{ft}$. long. Ore 
Red Devil - Continued

bodies are elongate, plunge southward, and ranged from a few inches to about $4 \mathrm{ft}$. in thickness and from a few to several hundred feet in length. Most ore formed by open-space fliling; some by replacing altered dike rock. Mine was Alaska's leading mercury producer unti1 it suspended operations in 1963. From 1939 to 1963 produced 20,000-25,000 flasks of mercury and a little byproduct antimony from about $9,600 \mathrm{ft}$. of underground workings on 5 main levels.

Hawley and others, 1969 (C 615) -- Reference to B 1187. Analyses of 3 samples of ore; in two Au is lese than in several common rock types. 
Rhyoltte

Anlak district

MF-368, 10c. 2
Aatimany, Mercury

Sleetmute $(5.2,16.8)$

$61^{\circ} 57^{\prime} \mathrm{N}, 158^{\circ} 22^{\prime} \mathrm{W}$

Sumery: On Jun1nggulia Mta., which is a large rhyolite porphyry body intruslve Into Cretaceous graywacke and shale. Related rhyolite porphry dikes and older, probably unrelated trachitlc (?) or diabasic (?) dikes and sills now altered to clay and carbonate minerals, quartz, and limonite cut sedimentary rocks. Small amounts of cinnabar in velnlets and pods in faults and shear zones in dikes and shattered graywacke. Only stibnlte found in area was a plece of float on mountain top. Discovered, 1956. Only exploration was trenching through 5-16 ft. of perennially frozen overburden.

Malone, 1962 (IC 8131), p. 43, 45 -- Bedrock 1s Uppex Cretaceous graywacke and shale and rhyolite extrusive rocks forming Juninggulra Mta. Stringers and lenses of clnnabar and atibnite occur near rhyolite-shale contacts. Maximum observed width of.minerallzed zones is $2 \mathrm{ft}$; cinnabar stringers are short, discontinuous, and erratic. A silica-carbonate s1ll contalns 1rregularly disseminated mercury mineralization. No mineralization in main rhyolite mass of Junlaggulra Mtn., but a few small clnnabar stringers were found in rhyolite about $3 \mathrm{ml}$. away.

Maloney, 1962 (RI 6141) -- Discovered, 1956. Some trenching and test pltting, 1957. USBM trenching, 1958-59. Country rock is Cretaceous sedimentary rocks, malniy shale and graywacke, of Ruskokw1m Gp. Igneous rock are 1n-. trusive albite rhyolite of Juninggulra Mtn, and probably older blotite basalt dikes and s11ls. Bedrock commonly covered by 5-16 feet of permanently frozen overburden. At prospect, dikes and sills of basalt now altered to allica-carbonate rock intrude sedimentary rocks. Cinnabar In sma11 lenses or short, thin stringers in silica-carbonate dikes and sills or along thelr borders. No cinnabar in rhyolite. Only stibnite found was a plece of float near top of mountaln. USBM bulldozed 26 trenches, collected 92 samples, and drtiled 12 auger holes.

Sainsbury and Mackevett, 3965 (B 1187), p. 46-49 - Graywacke and shale of Kuskokwim Gp. [Cretaceous] is cut by complexly orlented dikes and sills of at least 3 types and by a large mass of rhyollte porphyry. All dikes and sills except rhyolite porphyry are so intensely altered that the original composition 18 difficult to determine. Most common type 1s altered porphyritic rock contalning pyrite; relict trachitlc texture. Other dikes have amygdaloldal texture. Youngest dikes are rhyolite porphyry; undoubtedly offahoots of lerge mass of porphyry. Trenching through permanently frozen overburden disclosed small amounts of clnnabar in veinlets and pods; none more than a few Inches thick. In faults and shear zones in dikes and adjacent shattered graywacke. Some of cinnabar intergrown with small grains of hematite. Minerals in altered dikes are malnly clay and carbonate minerals, quartz and 11monfte. Property staked in 1957 and explored by pits and trenches. No production. sllver.

p. 80 -- Semlquantitative spectrograph1c analysis of a sample; $0.0015 \%$

Berg and Cobb, 1967 (B 1246), p. 92 -- Graywacke and shale cut by altered basaltic dikes and silis and at111 younger albite rhyolite dikes and sills. 
Rhyolite - Continued

Cinnabar, accompanted by small amounts of clay, occura in small lenses and stringers in altered basaltic intrusives and along contacts between them and graywacke and shale.

Hawley and others, 1969 (C 615), p. 16, 18-19 -- Reference to B 1187 . Analysis of ore sample; 15 ppm Ag. 
(TImber $\mathrm{Cr}$. )

Arlak distriet
Gold

Sleetmute $(0.75,0.5)$ approx. $61^{\circ} 02^{\prime} \mathrm{N}, 158^{\circ} 55^{\prime} \mathrm{w}$ approx.

Summary: Placer gold in creak that dralns area of Paleozolc (?)-Cretaceous clastic, volcanic, and carbonate rocks intruded by small albite-rhyolite bodies.

Cady and others, 1955 (P 268), P. 120 -- Placer gold present; has been prospecting; albite rhyolite intruslons in area. (Geologic map shows headwaters dralning area underla1n by Paleozolc (?)-Cretaceous clast1c, volcan1c, and carbonate rocks of Gemuk GP. Rest of basin in Cretaceous graywacke and ohale of Kuskokwim Gp. Four small albite rhyolite Intrusions shown near one fork.] 
Two Genevleves

Antak district

MF-368, 10c. 6
Mercury

Sleetmute $(13.95,14.5)$

$61^{\circ} 49^{\prime} \mathrm{N}, 157^{\circ} 19^{\prime} \mathrm{W}$

Summary: Cinnabar In vuga and breccla zone near upper contact of a 8111 altered to s1l1ca-carbonate rock; fragments of graphite also present In 8111 .

Cady and others, 1955 (P 268), p. 65 - Fragments of graphite in altered basalt. p. 111 -- Cinnabar locallzed in vugs and a breccla zone at upper border of a 8111 of sil1ca-carbonate rock.

Salnsbury and Mackevett, 1965 (B 1187), p. 20 -- Reference to P 268, p. 111. Cinnabar localized in vugs in a breccla zone near upper contact of an altered sill in graywacke and shale of Kuskokw1m Gp. 
Vermil11on

Anlak district

MF-368, 10c. 10
Antimony (?), Mercury

Sleetmute $(13.85,13.7)$

$61^{\circ} 46^{\prime} \mathrm{N}, 157^{\circ} 20^{\prime} \mathrm{W}$

Sumary: Cinnabar (and possibly stibntte) ta stringers along bedding planes of shale.

Cady and others, 1955 (P 268), p. 111 -- Clalm between Red Dev1l and Barometer mines. Ore minerals [assumed to be clanabar and possibly stibnite] as bedding stringers in shaly zone of interbedded graywacke and shale [of Cretaceous Kuskokw1m Gp.].

Salnsbury and Mackevett, 1965 (B 1187), p. 20 -- Clnnabar as stringera along bedding planes of shale; reference to $P 268, P .111$. 
W111s

Anlak district

MF-368, 10C, 5
Antimony, Mercury

Sleetmute $(13.55,14.4)$

$61^{\circ} 49^{\circ} \mathrm{N}, 157^{\circ} 22^{\prime} \mathrm{W}$

Summary: Cretaceous graywacke and shale that dip steeply SW are cut by dikes now altered to silica, limonite, and carbonate and clay minerals; small but abnormal amounts of apatite and sphene. Largest dike (20 ft. thick) nearly horlzontal. All bedrock cut by faults parallel to bedding. Cinnabar-bearing veins (as much as $50 \mathrm{ft}$. long and 6 1n. thick) In or near intrusive rocks. Cinnabar locally disseminated in fractures in dikes and enclosing rocks and in arglilized rock near dike contacts. Dlscovered, 1909. Developed by short ad1ts, p1ts, and trenches. Production was a few Elasks of mercury during World War I; some rich ore stockptled in 1958.

Smlth and Maddren, 1915 (B 622), p. 286 -- As of 1914, cInnabar had been found. Smlth, 1917 (B 655), p. 144-145 -- Cinnabar has been found; simflar to Parks property.

Brooks, 1923 (B 739), P. 13 -- Development, 1921.

Smith, 1929 (B 797), p. 41 -- Smal1-scale operation, 1926.

Joesting, 1942 (TDM 1), p. 24 -- Reference to B 655.

Sintth, 1942 (B 933 A), p. 91 -- Property leased, 1940.

Ba1n, 1946 (IC 7379), p. 63 -- Mercury prospect.

Webber and others, 1947 (RI 4065), p. 28-29-- 16 unpatented clatms. D1scovered 1n 1909. Developed by numerous test p1ts and trenches and a few short adits. Only production was a few flasks of mercury retorted from material removed during assessment work. Country rock 1s graywacke, sandstone, and shale Intruded by andesite dikes now hydrothermally altered. Cinnabar and attbnite mineralization mainly along hanging-wall contacts of dikes; some in fractures in dikes.

Cady and others, 1955 (P 268), p. 65 -- Long, crosscutting blotite basalt dike; one of few known in region.

p. 111 - Discovered, 1909. Numerous p1ts, trenches, short adits. During World War I a little more than 2 flasks of mercury was produced in an extemporized retort. Dikes of sillca-carbonate rock cut interbedded graywacke and shale; section overturned. Rocks above a dike are fractured and brecclated and dike $1 \mathrm{~s}$ broken by jolnts perpendicular to contact; cinnabar and stibnite in velns and 1ncrustations in openings.

Safnobury and Mackevett, 1960 (P 400-B), P. B38 -- Cretaceous graywackes and shales strike NW, dip steeply SW; altered dikes nearly horizontal. Ore bodles at and near intersectlons between altered dikes and faults that commonly strike parallel to bedding; ore bodies elongate horizontally and dip gouthward.

Jasper, 1961, p. 70-72 -- D1scovered 1909. Considerable test p1tt1ng and severa1 ad1ts. A few flasks of mercury produced in home-made retort. USBM trenchIng and sampling in 1943. More by owners in 1953-54. St1bnite and cinnabar in thin discontinuous velnlets and stringers, in small lenses or pods, and $a s$ blebs along fractures and shears in dikes and s1lls. Best concentrations in sheared shales and shear zone in sill parallel to border. Property might develop a large-tonnage, low-grade operation.

Malone, 1962 (IC 8131), p. 8 -- Discovered before World War II. Reference to RI 4065.

p. 13 - Altered diabase (?) dikes and sills. 
W1111s - Continued

p. 15 - Dikes appear megascoplcally to be the same as those at Red Dev11, Barometer, and Parks.

P. 35 -- Reference to RI 4065.

Mackevett and Berg, 1963 (B 1142-G), P. G7 -- Relict dlabas1c textures in thin sectlons of dikes.

Malone, I965 (IC 8252), P. 32, 46-47, 54 -- References to RI 4065 and IC 8131.

Salnsbury and Mackevett, 1965 (B 1187), p. 15-18 -- Staked in 1909. Development consisted of p1ts, trenches, and short ad1ts before 1942. Later work was excavation of bulldozer trenches that exposed sone new ore. Only a few flasks of mercury ever produced; some rich ore stockpiled in 1958. Bedrock exposed only In trenches. Graywacke and shale intruded by altered dikes and ofl1s. Matn intrusive appears to be a complex dike at least $20 \mathrm{ft}$. thlck. Dikes not all same age; some crosscut others. All bedrock cut by bedding-plane faults. Clnnabar-bearling velns (up to $50 \mathrm{ft}$. long and $6 \mathrm{ln}$. wide) in or near Igneous rocks. Cinnabar disgeminated locally in fractures in dikes and nearby sedimentary rocks or in argillized rock at contacts between intrusive rock and graywacke. Ore is cinnabar with or without stibnite; some pyrite, st1b1confte (?), and hematite. Gangue 18 quertz, carbonate, limonlte, and dicklte. Altered dike rock contalns apatite and sphene. Ore formed princlpally in velns along fractures where bedding-plane faults intersect intrusive rocks.

p. 81 -- Semiquantitative spectrographic analyols of sample.

Berg and Cobb, 1967 (B 1246), p. 92 -- A few flakk of mercury produced during World War I.

Hawley and otherg, 1969 (C 615), p. 16, 18-19 -- Reference to B 1187. Analys18 of an ore sample. 
Unnamed prospect

Anlak distrićt

MF-368, 1oc. 9
Antimony, Mercury

Sleetmute $(13.75,13.6)$

$61^{\circ} 46^{\prime} \mathrm{N}, 157^{\circ} 21^{\prime} \mathrm{W}$

Summary: Prospect reported to show cinnabar and stibnite.

Cady and others, 1955 (P 268), p. 111 -- Prospect reported to show cinnabar and stionite; SW of head of small creek that flows past Barometer mine. Sa1nabury and Mackevett, 1965 (B 1187), p. 21 -- Reference to P 268, p. 111. 
(Alder Gulch)

Anlak detrict
Mercury

Taylor Mts. (1.4, 13.0) $60^{\circ} 44^{\prime} \mathrm{N}, 158^{\circ} 50^{\prime} \mathrm{W}$

Summary: Ploat cinnabar

Rutledge, 1950 (RI 4719), p. 1, 3 -- Ploat clnnabar found In 1941. 
Broken Shovel

Anlak district

MF-384, 10c. 1
Antimony, Mercury

Taylor Mts. (1.25, 14.05)

$60^{\circ} 48^{\prime} \mathrm{N}, 158^{\circ} 51^{\prime} \mathrm{W}$

Sumary: Bedrock is Triasalc alltstone Intruded by a diabase dike or s111. A fault follows one margin of the dike or ol11 and containg discontinuous quartz velns that locally contain stibnite. No clnnabar seen in place, but tt and, reportedly, native mercury are common in float fragments as flilings of crose fractures and breccla openings. Staked In 1941 and explored by a l1ttle surface work that was not adequate to evaluate the prospect. Vague reports of minor production may be in error.

Webber and others, 1947 (RI 4065), p. 44-46 -- Located, 1941. Bedrock In reg100 1s Interbedded graywacke and shale of posstble late Paleozolc age; some Interbedded chert and Itmestone. Mainly basalt1c sills and lava flows. Some of sills hydrothermaliy altered. Clnabbar in all alluvial depostes near altered a111s. Cinnabar assoctated with small amounts of stibnite and minute amounts of native mercury; localized in bedding foints and small cross folnts and breccla zones lined wth vein quartz. [From a report preIninary to P 268].

Rutledge, 1950 (RI 4719), p. 4 -- Staked, 1941.

p. 8 -- Shallow prospect pits excavated to trace float clnnabar in Broken Shovel Gulch to source. Main showling 18 a narrow, 1rregular quartz vein locally contalning small lenses of etIbnite and minor amounta of cinnabar.

Cady and othere, 1955 (P 268), P. 115 -- Bedrock 1s siltstone of Gemuk Gp. (Tr1asa1c, see p. 33) and a111s of ell1ca-carbonate rock. Based on study of float fragments, minerals are coarsely crystalline, f1ll crose jolnts and breccla opentogs; cinnabar gives way to stibnite and quartz at lower elevations; native mercury reported. Fine particles of cinnabar fill cracks In altered ollvine phenocrysta in partialiy altered silis.

Jasper, 1961, p. 77-78 -- Staked, 1941.

Malone, 1962 (IC 8131), p. 39 -- Sma11 production.

p. 41,43 -- Located, 1941. Mineralization in sedimentary rocks Intruded by ol11s. Lode 18 irregular quartz veln with small lenses of cinnabar and stibnlte. Natlve mercury reported. Reference to $P 268$.

Malone, 1965 (IC 8252), p. 39, 53 -- Same as IC 8131.

Sa1nebury and Mackevetr, 1965 (B 1187), p. 40 - VertLcal diabase dike or a111 1-3 ft. wide; followed by a fault in which discontinuous quartz velns locelly contaln atibnite. No cinnabar seen im place, but has been panned from nearby stream. Not enough exploration for a valid evaluation of prospect.

Berg and Cobb, 1967 (B 1246), p. 93 -- Small amount of ore shlpped during World War II. 
(Car1bou Cr.)

Bristol Bay region
Gold (?)

Taylor Mes.

SE $1 / 4 \mathrm{NE} 1 / 4$ quad. (?)

Summary: May have been smal1-scale gold placer mining in early 1900's.

Mert1e, 1938 (\$ 903), p. 91 -- Sald to have been smal1-scale gold placer mining in early 1900's. 
CInnabar Creek

Anlak district

MF-384, loc. 1
Antimony, Gold, Mercury, Zinc

Taylor Mts. (1.25, 14.05)

$60^{\circ} 48^{\prime} \mathrm{N}, 158^{\circ} 5 I^{\prime} \mathrm{W}$

Summary: Dlabase dike, hydrothermally altered wlth much dicklte, cuts sheared and faulted graywacke and siltatone. Ore 18 along vertical faults parallel to dike; constats of small 1rregular velnlets malnly of cinnabar, stibntte, and quartz; clnnabar also dissemtnated and smeared on slickensided surfaces. Tenor of ore changes abruptly; ore bodies have aseay walla. Veln matertal contatne mtnor amounts of pyrite, sphalertte, dick1te, gypsum, and dolomite. Locally native mercury is common. Cinnabar in oplits of a sample contalned 0.14 ppm gold, the highest concentracton In any Alaskan ctnnabar sample. Mined by open cuts. Production, 1955-60, was more than 500 flesks of mercury (a11 from cinnabar; native mercury was not aaved).

Jasper, 1961, p. 78-79 -- Depos1t 1s north of Cinnabar Gulch. Source of al1 production from area, 1943-60; more than 500 flasks of mercury. Bedrock Is Interbedded shale and graywecke Intruded "by a11ls of Interlayered lava 1 lows and dikes that are commonly porphyritic andesite." Quartz diorite dikes and a111s reported in distrlct. Ore shoot mined in open cut 18 in a shear zone along a bedding fault at shale-andesite contact; mineralization largely in shale; some in outer foot or two of s1ll. Maximum width of one zone is $12 \mathrm{ft}$; 90-100 ft. 10ng. Mineralization is in discontinuous velnlets and atringers, short lenses and blebs. Ore minerals are cinnabar and native mercury. Some post-ore movement on fault.

Malone, 1962 (IC 8131), p. 2, 8 -- Has been production; discovered before [actually, dúring] World War II.

Malone, 1965 (IC 8252), p. 31, 53 -. Same as IC 8131.

Sa1nsbury and MacRevett, 1965 (B 1187), p. 3 -- In 1950's substantlal amounts of mercury was produced.

p. 35-40 -- Development began In 1954. Production, 1955-60, amounted to several hundred flasks. Dlamond dr111ing in 1961. Bedrock is Upper Triaseic interbedded graywacke, slltstone, volcanlc rocks and minor chert and IImestone of Gemuk Gp. Structure 1s complex; rocks at mine dip SW. Ore is along vertical faults parallel to an altered dlabase dike; wall rocks are graywacke and olltstone and are extensively sheared and altered. Most of movement was before infection of dike. Degree of alteration of dike decreases away from mine. Ore is sheared, argllilzed, Iron-Btalned graywacke and alltatone cut by many smal1 1rregular velnlet of cinnabar and stibntte; cinnabar also disseminated in altered rocks and ameared on slickenslded surfaces. Locally rich ore occurs slong rolls in faults. Tenor of ore changes abruptly; ore bodles have assay walls. Native mercury very abundant In gouge and quartz veln that branches from a fault; not recovered in mining. Some pyrite in ore. Alteratton of dike and wall rocks hydrothermal; much dicklte. Mining was from an open pit.

Berg and Cobb, 1967 (B 1246), P. 92 -- More than 500 flasks of mercury recovered from ore mined from open cuts between 1955 and 1960.

Hawley and others, 1969 (C 615), p. 18-20 -- Reference to B 1187. Analyses of splits of a sample of ctnnabar ore showed an average of $0.14 \mathrm{ppm}$ Au. The highest of any of the 19 samples of Alaskan mercury ore analyzed. 
Cinnabar Creek - Continued

U.S. Geological Survey, 1971 (P 750-A), p. A52-A53 -- Veln minerals at C1naabar Creek mine and adjacent prospects are primarliy clnnabar, otibnite, and quartz with minor amouts of pyrite, sphalertte, dicktte, gypsum, and dolomte; native mercury common. Deposits emplaced within major fault zones; at least 3 phases of cinnabar emplacement. 
(CInnabar Cr.)

Anlak district

MF-384, 10c. 9
Antimony, Mercury

Taylor Mts. (1.15-1.25, 13.9-14.05)

$60^{\circ} 48^{\prime} \mathrm{N}, 158^{\circ} 51^{\prime}-158^{\circ} 52^{\prime} \mathrm{W}$

Summary: Piacer depos1ts extend downstream from Cinnabar Creek lode mine. Clnnabar 1n stream gravels and on terrace remants about $60 \mathrm{ft}$. above creek. Test p1ts showed a mining section 5-14 ft. thick with mercury content varying from less than 0.1 pound to 0.84 pound per cuble yard. Has been production; amount of mercury recovered probably was small. Includes reference日 to: (Cinnabar Gulch), (CInnabar Run); see also Cinnabar Creek, Lucky Day.

Joest1ng, 1942 (TDM 1), p. 23-24 -- Several low-grade c1nnabar lode occurrenceg and a rich placer deposit (on Cinnabar Gulch). Pay gravel sald to be about a foot thick, on shale bedrock, and covered by 4-10 ft. of overburden. Hes been a amall ahipment cinnabar concentrates. Schaeffer and Winchell prospects. [Reference Includes lode prospects, but does not 1dent1fy them.]

Joesting, 1943 (TDM 2), p. 17 - Recent production (1942).

Webber and others, 1947 (RI 4065), p. 4 -- Examined by USBM, 1943.

p. 44-46 -- Located, 1941. For data on reglonal geology gee entry under Broken Shovel. Placer depostta on Clnnabar Cr. and Clnnabar Run are not far from a source of cinnabar near head of Cinnabar Gulch; lode looked for but not found. Some of placer material appears to have been reconcentrated from a bench $40 \mathrm{ft}$. above CInnabar Run.

p. 48 -- In Cinnabar Rum and Cinnabar Gulch alluvium 18 slide rock and grave1 5-10 ft. thick; cinnabar concentrated on bedrock. Some systematic prospecting in 1943.

Rutledge, 1950 (RI 4719), p. I -- H1gh-grade clnnabar float found, 1941.

P. 3-4 - Placer clalms staked, 1941, by Schaefer W1nche11 and Landru.

p. 9 - Trench $390 \mathrm{ft}$. long on Cinnabar Gulch upstream from Dlscovery clatm; maximum overburden was $18 \mathrm{ft}$; clnnabar on bedrock for length of trench, but no lode occurrence found. Altered basalt s111 with quartz velns crosses head of gulch. Rest of data same as RI 4065 Iquoted from USGS preIIminary report].

Cady and others, 1955 (P 268), p. 66 - Mercury depos1ts in azea are assoctated with altered blotite basalt s11ls of probable earliest Tertlary age.

p. 108 -- Deposits do not persist far below surface.

p. 115 -- Average depth to bedrock about 7 ft. Tested placer deposits from 1,000 ft. above mouth of CInnabar Gulch down to mouth of Cinnabar Run. Pay streak 2-6 1n. thlek and $25 \mathrm{ft}$. wide; elnnabar nuggets up to size of a f1ot. Nuggets increase in roundness downstream. Some have stibnite, quartz, and Dreccla fragments of siltatone attached. Lode source has not been found. At least one s111ca-carbonate s111 crosses gulch.

Jasper, 1961, p. 77-78 - Staked, 1941. Prospecting and gampling in 1943 did not develop an economlcally interesting yardage of material.

Malone, 1962 (IC 8131), P. 39 - Placer ground located, 1941.

p. 57 - Reference to p. 39.

Malone, 1965 (IC 8252), P. 40 - Same as IC 8131.

Salnsbury and Mackevett, 1965 (B 1187), p. 35 -- Placer cla1ms ataked, 1941. 
(CInnabar Cr.) - Cont1nued

p. 42-43 - Placer depostt extends downstream from plt of Cinnabar Creek lode mine. In stream gravels and remants of terrace gravels. Test pits showed a mining section 5-14 ft. thick with a mexcury content from less than $0.101 \mathrm{~b}$. to $0.84 \mathrm{lb}$. per cu. yd. of gravel.

Berg and Cobb, 1967 (B 1246), p. 92 - Placer ctnnabar has been mined.

Cobb, 1973 (B 1374), p. 46 - Cinnabar has been mined from placer; amount recovered was probably amal1. 
(Gemuk Mrn.)

Anlak destrict

MF-384, 10c5. 5, 10
Antimony, Gold, Mercury

Taylor Mts. (0.05-0.15, 10.25-10.35)

$60^{\circ} 35^{\prime} \mathrm{N}, 158^{\circ} 59^{\prime}-159^{\circ} 00^{\prime} \mathrm{W}$

Sumary: 3 randomiy selected samples of etibnite-r1ch pods and lenses in vetn quartz in fault gouge and breccla contatned 82-100 ppm gold. Zone 1s along contact between blotfte diorlte and homfelsed quartzite and shale. Cinnabar panned from creek draining area of velne, but not found In bedrock.

Clark and others, 1970 (OF 439), p. 3, 6-7 (1ocal1ty 6) -- Quartz-stibnlte vein appears to be in a sheared contact between blotite diorite and hornfelsed quartzlte and shale. Zone nearly vertical and at least $2 \mathrm{ft}$. wlde. Vein matertal in pods and lenses from $1 \mathrm{tn}$. to more than 6 in. thick in fault gouge and Dreccla. Indtvidual anhedral gratns of gold assoctated with otybnite-rich marging of pods and lenses; 3 rendomly selected samples contalned 82-100 ppm gold. Clnnabar panned from small stream draining veln area; none found in veln material. 
(King Salmon R.)

Brlatol Bay regton
Go1d

Taylor Mts.

SW 1/4 quad.

Summary: Coarse gold in upper valley; found in 2907.

Mertte, 1938 (B 903), p. 91 - Coarse gold found In upper valley in 1907. 
(L1ttle Taylor Mts.)

Anfak diatrlet
Copper

Taylor Mrs.

$\mathrm{NW} 1 / 4 \mathrm{NE} 1 / 4$ quad.

Sumary: Traces of copper.

Cady and others, 1955 (P 268), p. 122 -- Traces of copper were noted. [No other data given.] 
Lucky Day

AnLak dIstrict

MF-384, Ioc. 3
Ant1mony, Mercury

Taylor Mts. (1.35, 13.15)

$60^{\circ} 45^{\prime} \mathrm{N}, 158^{\circ} 51^{\prime} \mathrm{W}$

Sumary: Triassic siltstone and graywacke fntruded by sills or dikea nearly parallel to bedding. Some intrusives altered to silica-carbonate-clay rock. Cinnabar-stibnite-native mercury mfneralization in shear zone along margin of a s111, along bedding-plane faults, in cross folnts, and In breccla zones. Explored by open cuts and shallow shafts. 26 flasks of mercury produced from hand-sorted residual fidat, 1942-43. Some ore mined from altered Intrusive rock in 1954 stockp1led. See also (CInnabar Cr.).

Webber and others, 1947 (RI 4065), p. 4 -- Sampled by USBM, 1943.

p. 44-49 - Located, 1941. I5 flasks of mercury produced from 2,300 Ibs. of detrttal material In 1942; 11 flasks from 1,300 1bs. detrital materfal in 1943; no ore from lode 1tself. For data on reglonal geology gee entry for Broken Shovel. Deposit 18 a breccla filling in a fractured zone In graywacke. Cinnabar intergrown with stibnite and quartz in smal1, Irregular, lenticular masses. Gangue 1o quartz, calc1te, sand, clay, gouge, and altered graywacke. Explored by trenches and short adits through overburden. 9 channel samples by USBM contalned a welghted average of 10.5 1bs. per ton in a possible minerallzed zone $632 \mathrm{ft}$. Iong and $3.2 \mathrm{ft}$. wide. Overburden 5-10 ft. thick.

Rutledge, 1950 (RI 4719), p. 1 -- 26 flaske of mercury recovered from 3,600 1bo. of detrita1 ore, 1942-43.

p. 3-4 -- Staked, 1941, by Schaefer \& Winche11. 26 flasks of mercury from detrital ore; no minting of lode.

p. 6-8 -- Thin films of cinnabar associated with quaxtz and atibnite and small amount of native mercury along bedi1ng-plane faults, crosa Jolnts, and brecclated zones in graywacke and ahale. Samples contalned $0.03-1.35 \% \mathrm{Hg}$ and less than $0.2 \% \mathrm{Sb}$ (only $3 \mathrm{Sb}$ analyoes). Another type of depostt is associated with s111-11ke basalt 1ntrus1ves; lenticular pods of clnuabar parallel intrusives; lower grade minerallzation along beddingplane faults between pods and tntrusives. Production was from hand-sorted resldual materlal derived from these deposits. Pods of clnnabar (with stlbnite, quartz, native mercury) plach out horizontally and verticaliy.

Cady and others, 1955 (P 268), p. 113-115 - 26 flasks of mercury produced ma1nly from surface ptts and trenches. Blotite bagalt s111s, some now altered to all1ca-carbonate rocks, Intruded shaly rocks of Cretaceous Kuskokwim Gp. Lode contalne clnnabar, stibntte, native mercury, and dickite locallzed along and near hanglng walls of s111s. In upper part of lode cinnabsi in bedding-plane fractures; In lower part in cross jolnts and breccla openIngs. "Ore" decreases In IIchnesa with decrease in elevation. Operator (Schaefer) belleves that materlal that remains is too low grade to mine [as of about 1950?].

Jasper, 1961, p. 77-78 -- Located, 1941. 26 flasks of mercury recovered from weathered materta1, 1942-43.

Malone, 1962 (IC 8131), p. 8 - Found before World War II.

p. 39-43 - Located, 1941. 26 flasks of mercury recovered from 3,600 Ibs. of high-grade float, 1942-43. References to P 268, RT 4065, RI 4719. 
Lucky Day - Continued

Malone, 1965 (IC 8252), P. 32, 40-41, 53 -r Same as IC 8131.

Salnobury and Mackevett, 1965 (B 1187), p. 35 -- Reference to RI 4719.

p. 41-42 - By 1943, 26 flaoks of mercury was produced from hand-sorted ore from regidual placerg. In 1954 more than a ton of rich ore was mined from alcered Intrustve rock and stockptled. Country rock ts massive s11tstone and graywacke (Late Tr1agsic age) of Gemuk Gp. Lutruded by s111s or dikes nearly parallel to bedding; some of intrusives altered to allicacarbonate-clay rock. Explored by trenches, pits, shallow shafts. In one trench contact between $\mathrm{s} 111$ and afltstone is a fault. Contact zone sheared and altered; cinnabar and stibnite in quartz velnlets; small amounts of native mercury.

p. 80-81 -- Analyg1s of ore sample.

Berg and Cobb, 1967 (B 1246), p. 93 -- 26 lasks of mercury recovered during World War II.

Hawley and others, 1969 (C 615), p, 18-19 - Reference to B 1187. Analyaeg of 2 samples of cinnabar ore. 
(Mulchatra R.)

Bristol Bay region
Gold

Taylor Mes.

E $1 / 2$ SE $1 / 4$ quad.

Summary: Fine flour gold on river bars.

Martin and Katz, 1912 (B 485), p. 133 -- Fine flour gold on all rtver bars above roktalee $\mathbf{R}$. 
(Pulchatnachakcharak R.)

Brtatol Bay region
Gold

Tay 1 or Mte.

NW $1 / 4$ SE $1 / 4$ quad.

Summary: Colors of gold have been found. Thts 18 the stream now called McGeary Cr.

Mertle, 1938 (B 903), p. 91 -- Colors of gold have been found. 
Redskln

Anlak distriet

MP-384, 10C. 4
Mercury

Tay1or Mts. (1.4, 13.0)

$60^{\circ} 44^{\prime} \mathrm{N}, 158^{\circ} 50^{\prime} \mathrm{W}$

Summary: Sparee fllms of clmabar along bedding planes, crose jolnts, and In breccla zoner in graywacke and shale. No record of any production.

Webber and others, 1947 (RI 4065), P. 4 -- Investigated by USBM, 1943.

p. 44-47 -. For data on regtonal geology gee entry for Broken Shovel. No clnnabar occurrences found by USBM In 1943; examination was cursory.

Rutledge, 1950 (RI 4719), P. 4 -- Cla1m staked by Schaefer \& wnchell.

p. 8 -- Brtef examination by USBM in 1947. Sparse f1lms of clnnabar along bedding planes, cross jolnts, and in breccla zones in graywacke and ohale.

Cady and others, 1955 (P 268), P. 115 -- Lode sald to be comparable with, but less extensive than, Lucky Day.

Malone, 1962 (IC 8131), P. 39 - Clatm staked, 1941.

Satnsbury and Mackevett, 1965 (B 1187), p. 42 -- Quotat1on from RI 4719. 
Schaefer

Anlak district

MF-384, 10C, 2
Mercury

TayLor Mts. (1.35, 13.8)

$60^{\circ} 47^{\prime} \mathrm{N}, 158^{\circ} 51^{\prime} \mathrm{W}$

Sumary: Cinnabar and attbntte in quaxtz gangue in breccla zone tn siltstone and graywake. No record of any production. See also: Broken Shovel, Clnabar Creek, (CInnabar $C_{.}$), Lucky Day, Redskin (Schaefer owned ald of them).

Salngbury and Mackevett, 1965 (B 1187), p. 40-41 -- Breccla zone of varlable wdth parallel to bedding of chert and siltotone. Cinnabar and gtibnte in a quartz gangue that cements breccla fragments. Sulfideg in part interotftlal and in part replacing quartz and breccla fragments. Clnnabar erraticaliy distributed. Owner reported finding fossils replaced by solid clnabar. 
(Sleltat Mtn.)

Bristol Bay region

MF-384, 10c. 8
Gold, Tungsten

Taylor Mts. (17.0, 1.2) approx. $60^{\circ} 03^{\prime} \mathrm{N}, 157^{\circ} 04^{\prime} \mathrm{W}$ approx.

Sumary: Small granitic Intrusive body; gold discovered In about 1930 in sma11 quartz velns around periphery; wolframte in a pegmatite vein. Gold worth $\$ 200$ was recovered. Coarse colors of gold in a nearby creek.

Mertle, 1938 (B 903), P. 91 -- Smal1 body of granitlc rocks. Gold In ginall gash velns around perfphery. Lode gold worth $\$ 200$ was recovered. A few coarse colors of gold in a nearby creek.

Berg and Cobb, 1967 (B 1246), p. 14 -- Gold lode discovered about 1930; 8ma11 quartz velns near perlphery of small grantelc intrusive. A little wolframite in a pegmatite veln in same granttic body. 
(Stevens $\mathrm{Cr}$, )

Anlak distrlet

MF-384, 10C. 7
Tungsten

Taylor Mts. (14.1, 16.85) approx. $60^{\circ} 57^{\prime} \mathrm{N}, 157^{\circ} 21^{\prime} \mathrm{W}$ approx.

Summary: Wolframite ln vela-quartz float from contact aureole around Taylor Mts. grantte stock.

Cady and others, 1955 (2 268), p. 83 -. Wolframtte was found in a loose fragment of a milky quartz ve1n 21ke those that extend from borders of grantte stock Into contact metamorphtc zone [developed in rocks of Kuskokw1m Gp. (Cretaceous), according to geologic map].

p. 121 -- Loose specimen of wolframite, assoc1ated with veln quartz, collected from ridge west of Stevens $\mathrm{Cr}_{\mathrm{r}}$; apparently weathered from contactmetemorphtc zone north of Taylor Mts. grantte stock.

Cobb, 1973 (B 1374), p. 43, 46 - Wolftamtte in float. 
(Taylor Cr.)

Anlak diatrict

MF-384, 10C. 11
Gold, Mercury, TIn

Taylor Mts, (14.0-15.05, 15.45-16.0) $60^{\circ} 53^{\prime}-60^{\circ} 54^{\prime} \mathrm{N}, 157^{\circ} 15^{\prime}-157^{\circ} 22^{\prime} \mathrm{W}$

Sumary: Placer depostts contatn gold, clanabar, cassitertte, and pyrite. Production, mainly in 1950-51, was about 2,500 fine ounces of gold. Placers were probably dertved from contact zones around felsic bodies that intruded and altered clastic Cretaceous rocks to hornfels.

Cady and others, 1955 (P 268), P. 71 -- Gold concentrates contain much pyrite, possibly from source rocks simtlar to those exposed on sumtt of Little Taylor Mtg. where albite rhyollte sheets and surrounding sedimentary rocks are pyrtitized and serteltized or ollicteled.

p. 116 -- Placer gold probably derived from quartz fracture f111ings In breccla zones at or near contacts between siliclfied and serfcltized rhyolite and adjacent graywackes and ahales of Ruskokw Im Gp. [Cretaceous]. p. 119 -- Bedrock laterbedded shale and graywacke Intruded by large albite rhyolite sheets. Gold In stream gravel; average depth to bedrock about $10 \mathrm{ft}$. Cinnabar and casalterite with gold. Below Fork $\mathrm{Cr}$. concentrates contaln much pyrite probably derived from alliclfled and pyritized zone near rhyolite dikes at sumit of Little Taylor Mts. Production, mainly In 1950-51, was worth about $\$ 90,000$.

Cobb, 1973 (B 1374), p. 43 -- 2,000 [artthmet1c error; should be about 2,500] ounces of gold has been mined; accompanted by cassiterfte, clanabar, and pyrite. Probably derived from mineralized zones in Cretaceous clast1c rocks altered to hornfels around quartz monzonite stock In Taylor Mts. or from mineralization associated with rhyolite Intrusives in Little Taylor Mts. 
(Tikch1k Mer.)

Briatol Bay region
Go2d

Taylor Mts.

S. cen. $1 / 4$ SW $1 / 4$ quad.

Strumary: FIne placer gold reported to have been found on north and wept sides of Tikchik Mtn.

Mert1e, 19.38 (B 903), p. 91 -. Fine gold has been found along north and west flanks of mountain.

Eakfne, 1968 (EC 17), p. 8 - A 11ttle placer gold reportedly has been found on north and west aldes of mountata. 
Anlak district

Taylor Mte. (2.2,8.9)

MF-384, Ioc. 6

$60^{\circ} 30^{\prime} \mathrm{N}, 158^{\circ} 45^{\prime} \mathrm{W}$

Sumary: Arsenopyrtte and chalcopyrtte in quartz velns in hornfelsed shale and gragwacke near a felste dike. Copper staln on fracture surfaces.

Clark and others, 1970 (0F 439), p. 3,6 (locations 11-13) -- Shale and graywacke bornfelaed by rhyolite to dactte dike about $15 \mathrm{ft}$. wide. Quartz velng in homfels contain arsenopyrite and minor chalcopyrite; fracture aurfaces copper stalned. Stibnlte may be present, as antimony content of analyzed samples was hlgh. 
Synonyms, Claim Names, Operators, and owners

Many mines and prospects have undergone changes in both their own names and in the names of their operators and owners. All names that appear in the cited references appear in this sumary either in the first section as occurrence names or in this as synonyms. Descriptions of placer deposits commonly give little information on the location of individual mines or claims, so the names of all operators and owners of placer mines and claims are in this section with a notation to refer to the description of the stream that was mined or prospected. 
(Arcana Cr.) -- see (Marsh Mtn.)

DeCoursey Mountain Mining Co. -- see (Marsh Mtn.)

Feeder - - see (Marsh Mtn.)

(Feeder Cx.) - see (Marsh Mtn.)

(Kemuk Mtn.) -- see Humble Oil \& Refintng co.

(Kuktalf R.) -- see (Koktalee R.)

Moneta Porcuplne Mines, Ltd. -- see (Marsh Mtn.)

Moneta Porcupine Mining Co. -- see (Marsh Mtn.)

Rasmissen -- see (Marsh Mtn.)

Red Cap -- see (Marsh Mtn.)

Red Top -- see (Narsh Mtn.)

Red Top Mercury Mines, Inc. -- eee (Marsh Mtn.)

Red Top Mining Co. -- see (Marsh Mtn.)

Ryan - see (Marsh Mtn.)

3"W" - - see (Marsh Mtn.)

Waskey (, Wren \& Wolf) -- see (Marsh Mtn.) 
Alaska Mines \& Minerals, Inc. -- see Barometer, Falrview, Red Devil

Alice - see Alice \& Bessie

Bessie - gee Alice \& Bessie

Bettles -- see Clnnabar ChIef, (Kolmakof)

Buck - - see W11l1s

Cordero Mining Co. -- see Alice \& Bessie, Rhyolite

Decoursey Mountatn Mining Co., Inc. -- see Barometer, Red Devil

Dunkle - see Altce \& Bessie

Eur1ca - - see Red Devil

Fuller \& Willis - see Willis

Halvorson -- see Barometer, Red Dev11

Halvorson \& Mellick -- see Red Devil

Headache -- see Willis

Jack -- see W11l1s

Jaufok -- see (Kolmakof)

Kusko - - see Red Devil

Kuskokwim Mercury Co. -- see Cinnabar Chlef

Kuskokwim Mining Co. -- see Red Devil

Lind - - see (Kolmakrof)

Lyman -- see Red Devil

Lyman \& Struver -- see Rhyolite

(Mary Cr.) -- see (Murray Gulch)

Mellick \& Halvorson -- see Red Dev1l

Murphy \& W11lis - - see Barometer

New Idrla-Alaska Quickallver Mining Co. -- see Red Devil

Nick -- see WIIIIs

Parks -- see Alice \& Bessle, Barometer

Rabldoux -- see (Kolmakof)

Rellef - see Willis

Rhophs -- see Barometer

Sam -- see Willis

Schaefer -- see (Fortyseven Cr.)

Schmidt \& Stampe -- see Red Devil

Skidmore -- see Berometer

Struver \& Lyman -- see Rhyolite

Stuver -- see Rhyollte

Wamco -- see (Kolmakof)

Western Alaska Mintng Co. -- see (Kolmakof)

W1llis \& Fuller - - see W1ll1s

W1Ijis, Lyman (\& Mellick) -- see Allce \& Bessle

Wylie -- see Mountaln Top 
Bristol Bay Mining Co. -- see (Clnnabar Cr.)

(Canary Gulch) -- see Lucky Day

(Cinnabar Gulch) -- see (Cinnabar Cr.)

(Cinnabar Run) -- see (Cinnabar Cr.)

Landau -- see Broken Shovel

Landru -- see Broken Shovel, (Clnnebar Cr.)

(McGeary Cr.) -- see (Pulchatnachakcharak R.)

New York-Alaska (Gold Dredglng) Corp. -- see Broken Shovel, (Cinnabar Cr.), Iucky Day, Redskin

Schaefer \& Winchell -- see (Cinnabar Cr.), Lucky Day, Redskın 


\section{References Cited}

References are 11sted, by quadrangle, In atandard format alphabet1cally by author and, secondar1ly, chronologically if an author prepared more than one report or map. Th1s section was prepared by stacking bibllography cards in a document protector and duplicating them on an office copylng machine. Th1s procedure makes retyping unnecessary, but has the disadvantages that the edges of cards reproduce as horizontal Ines between entrles and that margins and apacing are not constant. 
Berg, B. A., and Cobb, E. H., 1967, Metalldferous lode deposits of Alaska: U.S. Geol. Survey Bal1. 1246, 254 p.

Cobb, E. B., 1972, Metellic mineril resources map of the D111ingham quadrengle, Alakica! U.S. Geol. Survey Mtsc. Fleld Studies Map MF-375, 1 sheet, scale 1:250,000.

Cobb, E. H., 1973, Placer deposits of Alaska! U.S. Geol. Survey Bull. $1374,213 \mathrm{p}$.

Eakins, G. R., 1968, A geochemfcal investigation of the Wood RiverTikchlk Lakes area, southwestern Alaska: Alaska DIv. Mines and Minerals Geochem., Rept. 17, 31 p.

Hawley, C. C., Martinez, E. E., and Marinenko, John, 1969, Geocberalcal data on the South ore zone, White Mounta1n mine, and on the gold content of other mercury ores, southwestern Alaska, in Some shorter mineral resources invest1gations in Alaska: U.S. Geol. Survey Circ. 615, p. 16-20.

Joesting, H. R., 2943, Supplement to Pamphlet No. 1 - Strategle mineral occurrences in 1nterior Alagka: Alaska Dept. Mines Pamph. 2, $28 \mathrm{p}$.

Katz, F. J., 1910, Gold placers of the Mulchatna: U.S. Geol. Survey Bull. 442 , p. $201-202$.

Malone, Kevin, 1962, Mercuny occurrences in Alasks: U.S. Bur. Mines Inf. Circ. $8131,57 \mathrm{p}$.

Malone, Kevin, 1965, Mercury in Alaska, in 0. S. Bureau of Mines, Mercury potential of the United Stätes: U.S. Bur. Mines Inf. C1rc. 8252 , p. 31-59.

Mertin, G. C., and Katz, F. J.2 1919, A geologic reconnalssance of the. Iltamn reglon, Alaska: U.S. Geol. Survey Bull. 485, $138 \mathrm{p}$.

Mertie, J. B., Jr., 1938, The Nushagalk district, Alakka: U.S. Geol. Survey Bull. 903, 96 p.

Pennington, J. W., 1959, Mercury. A moterlals survey, with a chepter on Resources, by Edgar H. Belley: U.S. Bur. MEnes Inf. C1rc. 7941, $92 \mathrm{p}$.

Salinsbury, C. L., and Mackevett, E. M., Ir., 1960, Structural control in five quicksilver, deposits in southwestern Alaska; in Geolog1cal Survey research 1960: U.S. Geol. Survey Prof. Faper 400-B, p. B35-B38.

Sainsbury, C. L., and Mackevett, E. M., IY., 1965, Qutcksilver deposits if soutbwestern Alaska: U.S. Geol. Survey Bull. 1187 , $89 \mathrm{p}$. 
Sith, P. S., 1915, Mineral resources of the Laike Clark-Iditarod reglon! U.S. Geol. Survey Bull. 622, p. 247-271.

Smith, P. S., 1917, The Lake Clark-central Kuskokwim reglon, Alaska: U.S. Geol. Survey Bull. 655, 162 p.

Webber, B. S., Bjorkiund, S. $C_{.}$, Rutledge, F. $A_{i}^{\circ}$, Thomes, B. $I_{.}$, and Wright, W. S., 1947, Mercury deposits of southwestern Alaska: U.S. Bur. Mines Rept. Inv. 4065, 57 p. 
Batley, B. H., and simdth, R. M., 1964, Mercury - 1ts occurrence and economic trends: U.S. Gool. Survey CIre. 496, 11 p.

Bain;"H. F., 1946, Alaska's minerals as a basis for 1nidustry!

U.S. Bur. Mtnes Inf. Circ. 7379,89 p.

Berg, H. C., and Cobb, E. H., 1967, Netalifferous lode deposits of Alaska: U.S. Geol. Survey Bull. $2246,254 \mathrm{p}$.

Brooks, A. H.; 1911, Geologle features of Alasken metalliferous lodes: U.S. Geol. Survey Bull. 480, p. 43-93.

Brooks, A. H., 1915, the Alaskan mfning industry in 1914! U.S. Geol. Survey Bull. 622, p 15-68.

Brooks, A. H., 1916, The Alaskan minting industry in 1915: U.S. Geol. survey Buבl. 642, p. 16-71.

Brooks, A. H., 1916, Antimony deposits of Alaske! U.S. Geol. Survey Bull. 649, $67 \mathrm{p}$.

Brooks, A. H., 1918, the Alaskan minting industry in 1916: U.S. Geol. Survey Bull. 662, p. 11-62.

Brooks, A. H., 1919, Alakka's mineral supples: U.S. Geol. Survey Bull. 666, p. 89-102.

Brooks, A. H., 1921, The future of Alaske minting! v.S. Geol. Survey Bull. 714, p. 5-57.

BrookB, A. H., 1922, The Alaskan mining industry in 1920: U.S. Geol. Survey Bunl. 722, p. 7-67.

Brooks, A. H., 1923, The Alaskan minting Industry in 1921: U.S. Geol. Survey Bull. 739, p. 1-44.

Brooks, A. H., 1925, Alaska's mineral resources and production, 1923! U.S. Geol. Survey Bull. 773, p. 3-52.

Brooks, A. H., and Martin, G. C., 1921, The Alaskan minting 1udustry in 1919: U.S. Geol. Survey Bull. 714, p. 59-95.

cady, W. M., Wallace, R. E., Hoare, J. M., and Webbex, E. J., 1955, The central Kuskokwim region, Alaska: U.S. Geol. Survey Prof. Paper 268, $132 \mathrm{p}$.

Chapman, R. M., and Shacklette, H. T., 1960, Geochemical exploration In Alaska, in Geological Survey research 1960: U.S. Geol. Survey Prof. Paper 400-B, p. B104-B107.

Cobb, E. H., 1972, Metalilc wheral resources wap of the sleetwute quadrangle, Alaska! U.S. Geol. Survey MHsc. Fleld studies Map MF-368, 1 sheet, scale 1:250,000. 
Cobb, E. H., 1973, placer deposits of Alakka! U.S. Geol. Survey Bull. $1374,213 \mathrm{p}$.

Eaking, G. R., 1968, A geochemical Investigation of the wood RtverTHkchlk Lakes area, southwestern Alaska: Alaska D1v. Mines and Minerals Geochem. Rept. 17, 31 p.

Hawley, C. C., Martinez, E. E., and Marlnenko, John, 1969, Geochemlcal data on the South ore zone, White Mountain mine, and on the gold content of other mercury ores, southwestern Alaska, in Some shorter mineral resources investigations in Alaska: U.S. Geol. Survey C1Tc. 615, p. 16-20.

Jasper, M. W., 1961, Cinnabar province, Kuskokwim region, in Alabka Division of Mines and Minerals, Report for the year 1961: Juneau, Alaska, p. 65-79.

Jasper, M. H., 1963, garvison mercury prospect, in Alaska Division of Mines and Minerals, Report for the year 1963! Juneau, Alaska, p. 5l-52.

Joestins, H. R., 1942, Strategle mineral occurrences in interior Alaska: Alaska Dept. Mines Parph. 1, $46 \mathrm{p}$.

Joesting, H. R., 1943, Supplement to Pamphlet No. 1 - Strateg1c minerail occurrences in interior Alaska: Alaska Dept. Mines Pamph. 2, $28 \mathrm{p}$.

Mackevett, E. M., Jr., and Berg, H. C., 1963, Geology of the Red Dev11 quicks1lver mine, Alaska: U.S. Geol. Survey Bull. 2142-G, p. GI-GI6.

Maddren, A. G., 1915, Gold placers of the lower Kuskokwim with a note on copper in the Russian Mountalns: U.S. Geol. Survey Bull. 622, p. 292-360.

Malone, Kevin, 1962, Mercury occurrences in Alaska! U.S. Bur. Mines Inf. Circ. 8131, 57 p.

Malone, Kevin, 2965, Mercury in Alaska, in U. S. Bureau of Mines, Mercury potential of the United States: U.S. Bur. Mines Inf. C1rc. 8252, p. 31-59.

Maloney, R. P., 1962, Trenching and sampling at the Phyoltte mercury prospect, Kuskokwlm RIver basin, Alaska: U.S. Bur. Mines Rept. Inv. $6141,43 \mathrm{p}$.

Maloney, R. P., 1968, Soll soling at the Creek mercury prospect, Kuskokwlm RIver basin, Alaske: U.S. Bur. Mines openf1le rept. 16-68, $6 \mathrm{p}$.

Maloney, R. P., 1969, Sampling for gold in river bars, Kuskokwlm R1ver basin, Alaska: U.S. Bur. Mines open-11le rept. 16-69, $10 \mathrm{p}$. 
Martin, G. C., 1919, The Alaskan minting 1ndustry in 1917: U.S. Geol. survey bull. 692, p. $11-42$.

Merr131, C. W., Ir., and Maloney, R. P., 1974, Kolmakol mercury deposits: U.S. Bur. Mines open-file report 21-75, 21 p.

Mertle, J. B., Jr., 1923, The occurrence of metalliferous deposits in the Yukon and Kuskokwim regtons: U.S. Geol. Survey Bull. 739, p. 149-165.

Mertfe, J. B., Jr., 1936, Mitnerel deposits of the Ruby-Kuskokwim region, Alaska: U.S. Geol. Survey Bull. 864-C, p. 115-255.

Mertie, J. B., Jr., and Harrington, G. L., 1916, Mineral resources of the Ruby-Kuskokwin region: U.S. Geol. Survey Bull. 642, p. 223-266.

Mert1e, J. B., Jr., and Barrlngton, 1924, The Ruby-Kuskokwim region, Alaska: U.S. Geol. Survey Bull. 754, 129 p.

Moffit, F. H., 1927, Mineral industry of Alaska in 1925: U.S. Geol. Survey Burl. 792, p. 1-39.

Pennington, J. W., 1959, Mercury. A moterlals survey, with a chapter on Resources, by Edgar H. Bafley: U.S. Bur. Mines Inf. Circ. 7941, 92 p.

Salnsbury, C. L., and Mackevett, E. M., Jr., 1960, Structural contro1 In five quicksilver deposits in southwestern Alasks; in Geological Survey research 1960: Ut.S. Geol. Survey Prof. Faper 400-B, p. B35-B38.

Sainsbury, C. L., and Mackevett, E. M., Jx., 1965, Quicksilver deposits of southwestern Alaska: U.s. Geol. Survey Bull. 1187 , 89 p.

Smith, P. S., 1915, Mineral resources of the Lake Clark-Idttarod region: U.S. Geol. Survey Bull. 622, p. 247-271.

Smith, P. S., 1917, The Lake Clark-central Kuskokwim region, Alaska: U.S. Geol. Survey Bull. 655, 162 p.

Sintth, P. S., 1929, Mineral industry of Alaske in 1926: U.S. Geol. Survey Bull. 797, p. 1-50.

Smith, P. S., 1932, Mineral Industry of Alaska in 1929: U.S. Geol. Survey Bull. 824, p. 1-81.

Smlth, P. S., 1933, Mineral industry of Alakk in 1930: U.S. Geol. Survey Bull. 836, p. 1-83.

sint th, P. S., 1933, Mineral Industry of Alaska in 1931: U.S. Ceol. Survey Bu21. 844-A, p. 1-82. 
Buth, P. S., 1934, Mtrerel Industry of Alaske in 1932: U.S. Geol. Survey Bu11. $857-A$, D. 1-91.

Omith, P. S., 1934, Mineral industry of Alaska in 1933! U.S. Geol. Survey Bull. 864-A, p. 1-94.

Smith, P. S., 1936, Minerel induatry of Alaske in 1934: U.S. Geo1. Survey Bull. 868-A, p. 1-91.

South, P. S., 1937, Mtneral ladustry of Alaske in 1935: U.S. Geol. Survey Bull. 880-A, P. 1-95.

Smlth, P. S., 1938, Mineral 1ndustry of Alaska in 1936: U.S. Geol. Survey Bull. 897-A, p. 1-107.

Smith, P. S., 1939, Mineral Industry of Alaska in 1937: v.S. Geol. Survey Bull. 910-A, p. 1-113.

Smlth, P. S., 1939, Mineral 1nduatry of Alaska in 1938: U.S. Geol. Survey Bull. 917-A, p. 1-113.

Stinth, P. S., 1942, Mineral industry of Alaska in 1940: U.S. Ceol. Survey Bull. 933-A, 8. 1-102.

Sintth, P. S., and Maddren, A. G., 1915, Qufckollver deposits of the Kuskokwim region: U.S, Geol. Survey Bull. 622, p. 272-291.

Sorg, D. H., and Eatlund, M. B., 1972, Geologte map of the Mountaln Top mercury deposit, southwestern Alaska! U.S. Geol. Survey Mibe. Field Studies Map MF-449, scale $1: 600$.

Spurr, J. Ee, 1900, A reconnalssance in southwestern Alaska in 1898: U.S. Geol. Survey 20th Ann. Rept., pt. 7, p. 31-264.

U.S. Geological survey, 1964, Geologtcal survey research 1964! U.S. Geol. Survey Prof. Paper 501-A, p. Al-A367.

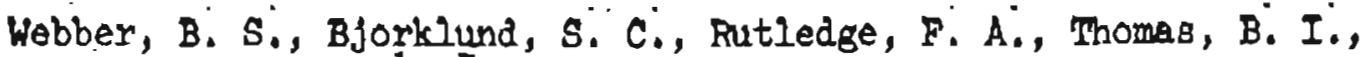
and Wright, W. S., 1947, Mercury deposits of southwestern Alaska: U.s. Bur. Mines Rept. Inv. $4065,57 \mathrm{p}$. 
Berg, H. S., and Cobb, E. H., 1967, Meto:l1ferous lode jepostts of Alzaka: U.S. Geo\}. Survey Bull. 1246, 254 p.

Cady, W. M., Wallace, R. E., Hoare, J. M., and Webber, E. J., 1955, The central Kuskokin region, Alaska: U.S. Geal. Survey Prof. Paper 268, 132 p.

Clark, A. I., Condon, W. H., Hoere, J. M., and Sorg; D. H., 1970, Analyses of rock and stream-sediment samples from the Taylor Mountains C-8 quadrangle, Alaska: U.S. Ceol. Survey open-Plle report 439, $110 \mathrm{p}$.

Cobb, E. H., 1972, Meta111c mineral resources mo of the Trylor Mountains ousdrangle, Alaska! U.S. Geol. Survey Misc. Fleld Studies F.3p MF-384, I sheet, scole 1:250,000.

Cobb, E. H., 1973, Placer áposits of Alsska! U.S. Geol. Survey Bull. $1374,213 \mathrm{p}$.

Eakins, G. R., 1968, A geochenical investigation of the Wood RiverTikchik Lakes area, southwestern Alaska: Alaska Div. Mines and Minerals Geochem. Rept. 17, 31 p.

Hawley,.C. C., Martinez, E. E., and Martnenko, Jobn, 1969, Geochemical. dats on the South ore zone, White Mountain mine, and on the gold content of otber mercury ores, southwestern Alaska, in Some sborter mineral resources investigations in Alaska: U.S. Geal. Survey Circ. 615, p. 16-20.

jasper, M. W., 1961, Cinnabar province, Kuskokwim region, in Alaske Division of Mines and Minerals, Report for the year 1961: Juneau, Alaska, p. 65-79.

Joesting, H. R., 1942, Stretegic mineral occurrences in intertor Alaska: Alaska Dept. Mines Pamph. 1, 46 p.

Joest1ng, B. R., 1943, Supplement to pamplet No. 1 - Strategle mineral occurrences in interior Alaska: Alaska Dept. Mines Pamph. 2, 28 p.

Malone, Kevin, 1962, Mercury occurrences in Alaska: U.S. Bur. Mines Inf. C1re. 8131, $57 \mathrm{p}$.

lialone, Kevin, 2965, Mercury in Alaska, in U. S. Bureau of Mines, Mercury potential of the United States: U.S. Bur. Mines Inf. Circ. 8252, p. 31-59.

Martin, G. C., and Katz, F. J.2 1912, A geologic reconnalssance of the, Iliamna region, Alaska: U.S. Geol. Survey Bull. 485, 138 p.

Mertie, J. B., Jr., 1938, The Nushagak district, Alaska: U.S. Ceol. Survey Bull. 903,96 p.

Rutledge, F. A., 1950, Investigation of mexcury deposits, Clnnabar Creek area, Georgetown and Akiak districts, Kuskokwim region, southwestern Alaska: U.S. Bur. Mines Rept. Iav. 4719, 9 p. 
Sainsbury, C. L., and Mackevett, E. M., J̣., 1965, Quicksilver depozits of southwesterm Alaska: U.S. Ceol. Sirvey Bull. 1287 , 89 p.

U.S. Geological survey, 1971, Geological survey research 1971! U.5. Geol. Survey Prof. Paper 750-A, p. Al-A418.

Webber, B. S., Bjorklund, S. C., Futledge, F. A., Thomes, B. I., and Wright, W. S., 1947, Mercury deposits of southwestern Alaska: U.S. Bur. Mines Rept. Inv. 4065, 57 p. 